\title{
THE MANUSCRIPT POEMS OF HENRY HOWARD, EARL OF SURREY.
}

There are now available seven manuscripts, all in the British Museum, which contain poems of Surrey. These mss. are Egerton 2711, Harleian 78, Hargrave 205, and Add. 17492, 28635,28636 , and 36529. The first of these is the precious ms. which contains the autograph poems of Wyatt, a transcript of which was published in Anglia, vols. 17-18.1) Dr. Nott's detailed account of the ms. may be found in the introductory pages to this transcript. With the exception that the twelve French epigrams on pages 227-235, and the short sentences on pages 206-207, are probably not in the handwriting of Wyatt, Nott's description is accurate. Unfortunately this ms. contains only one of Surrey's poems, which is a tribute to Wyatt, 'The great Macedon that out of Perse chased'. The ms. will be known as E. Ms. Harl. 78 [Harl.] is a miscellany, and contains, among other papers, a few stray leaves from some lost ms., which furnish several poems by Wyatt, and three by Surrey, 'Of thie lyff Thomas the compas well marke', 'I that vlisses yeres have spent', elsewhere not attributed to Surrey, and seven verses of the poem, ' $O$ happy dames that may embrayes'. The script is Elizabethan. Ms. Harg. 205 [Hary.] contains Surrey's translation of the fourth book of the Aeneid. The age of the ms., and the relative reliability of this version of the translation, are ably discussed by Dr. Rudolf Imelmann, in an article entitled Surrey's Aeneis IV in ursprünglicher Gestalt, in the Jahrbuch der Deutsch. Shakesp.-Gesellschaft, 1905.

1) Flügel, Die Handschriftliche Überlieferung der Gedichte von Sir Thomas Wyatt.

Anglla. N. F. XVII. 
Add. Ms. 17492 [D.] is the so-called Duke of Devonshire Ms., which contains a large number of Wyatt's poems not to be found elsewhere, and autograph poems of other writers of the time of Henry the VIII. Dr. Nott's description of this ms., together with the catalogue entry, is also printed in Anglia. It contains only one of Surrey's poems, ' $O$ happy dames that may embraes'. Add. Ms. 28635 [A.] claims to be an exact transcript of the so-called Harrington Ms. No. ii, which Nott used in his edition of $1815-16$, but which has since been lost. Besides poems by Sir John Harrington, John Harrington, his father, Sidney, Constable, and others, it contains about sixty of Wyatt's poems, and eleven of Surrey's. This ms. is more fully described in Professor Flügel's introduction. Add. $M s .28636$ is a good copy of $E$, but as the Museum now has the original, we need not consider this ms. Lastly, there is $M s .36529[P$.$] , which contains more of Surrey's poems than$ all other mss. together. In the Nachwort to his transcript, Professor Flügel calls attention to a ms. containing poems by Surrey and other writers, which was offered for sale by Mr. B. Quaritch. In 1900 this ms. was acquired by the Museum, and enrolled as $A d d$. 36529. As this ms. is peculiarly rich, not only for the student of Wyatt and Surrey, but of sixteenth century poetry in general, I will give the catalogue entry entire:

'Poems, by Henry Howard, Earl of Surrey (d. 1547), Sir Thomas Wyat (d. 1542), and others, apparently collected by Sir John Harrington of Kelston (d. 1612): -

1. "Helen to Paris"! a translation of Ovid, Heroid., Ep. xvii., by Sir Thomas Chaloner (d. 1565). Beg. "Now that myn eyes thy pistle red alredy haue suffred stayn." f. 5. Printed from this ms. in Nugae Antiquae (ed. Park, 1804), II. p. 372.

2. Translation of Virgil's Aeneid, libb. I-III (by Thomas Phaer, d. 1560). Beg. "I that some time my slender flute, in verse was wonte to sounde". ff. 10, 21, 36. In the first edition, The seuen first bookes, etc., 1558, Phaer states that these three books were finished 10 Oct. 1555 . The present text varies slightly from the printed editions, and perhaps represents an earlier draft.

3. Seven pieces by Sir Thomas Wyat, printed (with some variations) in Works of Surrey and Wyatt, ed. G. F. Nott, 
1815-16, vol. II., viz.: (I.) "Myne owne J[ohn] P[oynz] sins you delite to knowe" (Works, p. 87). f. 30 ; - (II.) "I finde no peace and all my war is done." (p. 9). f. 32 ; - (III.) "Venemous thorns that be both sharpe and keene" (p. 73). f. 32 ; - (IV.) "I am not dead although I had a fall" (p. 73). f. 32; - (V.) "Luckes my faire falcon and your fellowes all" (p. 72). f. $32 \mathrm{~b} ;-(\mathrm{VI}$.) "A face that shuld content me wonders well" (p. 64). f. $32 \mathrm{~b}$; - (VII.) "The wandring gadling in the somer tyde" (p. 67). f. 32 b.

4. Four pieces, printed in Nugae Antiquae (ed. 1779), III. (pp. 249-253, as Nos. 8, 9, 6, 7 of "Sonnets by John Harington, Esq., and some others, 1547, "viz.: (I.) "Playn ye my neyes": a translation of Petrarch, Sonnet 63. f. 33; - (II.) "I see my plaint". f. 33 ; - (III.) "Vengaunce must fall on thee" (Petrarch, Son. 105). f. $35 \mathrm{~b}$; - (IV.) "Spring of all woe" (Son. 107). f. $35 \mathrm{~b}$.

5. "None can deame right who faythfull frends do rest": Bk. XIX., stanza I. of Sir John Harington's translation of Orlando Furioso, first printed in 1591. f. 44.

6. Two anonymous pieces, (I.) "You on whose necks the waight of rewll doth rest", addressed to the English Judges or Privy Councillors; - (II.) "Whear giltles men ar greuously opreste". ff. $44,44 \mathrm{~b}$.

7. Translations from Petrarch: (I.) "You that in rime" (Sonnet I); - (II.) "Yf loue be not" (Son. 102); - (III.) "Some kind of creaturs" (Son. 17. Other versions, by Wyatt and Puttenham, are printed by Nott, Surrey and Wyatt, II. pp. 7, 540); - (IV.) "Cesare what time the wise" (Son. 81. Cf. Wyatt's version, op. cit. II. p. 6); - (V.) "If stable mynd and hart" (Son. 188. C'f. Wyatt, op. cit. p. 14); - (VI.) "Blest be the day" (Son. 47); -- (VII.) "From babells bowre" (Son. 91); - (VIII.) "Haniball woon and after cold not sew" (Son. 82); - (IX.) "The precius piller perisht is" (Son. 229. Cf. Wyatt in op. cit. II. p. 16); - (X.) "Now I bewayle", and (XII.) "I do bewepe", two versions of Son. 313 ; - (XI.) "The belye cheere" (Son. 7). ff. $45-48$.

8. "Severall Poems by the right Hon able Henry, Earle of Surrey", viz.: (I.) "The sonne hath twyse" (Nott, op. cit. I. p. 1). f. 50 ; - (II.) "So crewell prison" (ib. p. 48) f. 51; - 
(III.) "London, hast thow accused me" (ib. p. 53. First printed, from this ms., by Park in Nugae Antiquae, 1804, II. p. 336. Nott took his text from "the larger ms. in Dr. Harington's possession", as being less faulty). f. 52 ; - (IV.) "Suche waywarde wais" (Nott. I. p. 24). f. 53; - (V.) "As ofte as I behold" (ib. p. 7). f. $53 \mathrm{~b}$; - (VI.) "When youthe had ledd me" (ib. p. 23). f. 54; - (VII.) "Marshall the thinges" (ib. p. 43). f. 54 b; - (VIII.) "From Tuscane came" (ib. p. 3). f. 55; (IX.) "When Windesor walles" (ib. p. 50). f. 55; - (X.) "I neuer saw youe" (ib. p. 17, but with many variations). f. $55 \mathrm{~b}$; - (XI.) "Love that doth raine" (ib. p. 16). f. 55 b; - (XII.) "In Cipres springes" (ib. p. 18). f. $56 ;$ - (XIII.) "The greate Macedon" (ib. p. 44). f. 56 ; - (XIV.) "In the rude age" (ib. p. 47). f. $56 \mathrm{~b} ;-$ (XV.) "Thassyryans king" (ib. p. 44). f. $56 \mathrm{~b}$; - (XVI.) "Yf he that erst" (ib. p. 5). f. $56 \mathrm{~b} ;-$ (XVII.) "Set me wheras the sonne" (ib. p. 15). f. 57 ; - (XVIII.) "Dyvers thy death" (ib. p. 46). f. 57. At the end, in a later hand, "Here ends my $\mathrm{L}^{\mathrm{d}}$ of Surrey's Poems." But see below, artt. 9, 10.

9. Paraphrase of Ecclesiastes, chapp. I-IV [by Surrey]. Beg. "I salamon dauids sonne". f. 58 b. First printed by Park, from this ms., Nugae Antiquae, 1804, II. p. 339; afterwards by Nott, op. cit. I. p. 66, "from another ms. in Dr. Harington's possession".

10. Paraphrase of Psalms LXXXVIII., LXXIII., LV. [by Surrey]. Proem beg. "Wher reckeles youthe". f. 63. Printed (as above, art. 9) by Park, Nugae Antiquae II. p. 360, and Nott, I. p. 78.

11. "Advice to his Wife" [by John Harington, father of Sir John]; beg. "If dutie, wyf, leade the to deeme". f. 69. Printed, with date 1564, in Nugae Antiquae, 1779, III. p. 294 (ed. 1804, II. p. 395).

12. Various anonymous pieces, viz.: (I.) "Now hope, now feare, now ioye, now wofull cace" (6 lines). In the autograph of Sir John Harington (cf. Add. ms. 18920). f. $46 \mathrm{~b}$; - (II.) "Who so can way, of eache atempt the end" (14 vs., with a couplet added at the end). f. $66 \mathrm{~b}$; - (III.) "At lest withdraw your creweltie", in 5 stanzas of 9 lines; not the same as Wyatt's poem (Nott, II. p. 209), though in the same metre. f. $67 \mathrm{~b}$; - (IV.) "What natures woorke is this in one wightes 
corps to hyde (70 vs.). f. 80 ; - (V.) "So luckie be your twistid holde of copled youthe" (31 vs.) f. $81 \mathrm{~b}$.

13. Nascentis Ecclaesiae generatio prima: hoc est, Catalogus Pontificum Romanorum Caesarum patrum et rerum aliquot insignium post Christi servatoris ascensionem ad annum domini septuagesimum. "By Edmund Campion (d. 1581). Latin. In hexameters, beg. "Sancta salutiferi nascentia semina verbi", and preceded by a prose dedication addressed from Oxford (which Campion left in 1569, see R. Simpson, Edmund Campion, 1867, p. 22) to Anthony Browne, Viscount Montagu [15541592]. f. $69 \mathrm{~b}$. Not mentioned by the biographers of Campion.

At f. 82 is a deathbed speech of "Mr. Diringe" [? Edward Dering the puritan, d. 1576].

Paper; ff. 82. Late XVI. cent. Bound in brown leather with gilt- and blind-tooling, much defaced. On f. $29 \mathrm{~b}$ are the names "ffrancis Haryngton" and "Ellina Haryngton" (? signatures of two daughters of Sir John, d. 1636 and 1638 respectively, or perhaps the former signature is that of his younger brother, d. 1639: sre Misc. Gen. et Her., New Ser. IV. pp. 191193); the latter is repeated on f. 82 . On f. 3, "Liber Jacobi Tyrrell, 1663". Belonged in 1791 to the Rev. W. Sayle, of Stowey, co. Somerset (f. 1), and was apparently lent by him to Thomas Percy, Bishop of Dromore and editor of the Reliques, who has inserted notes at ff. $4,49 \mathrm{~b}, 62 \mathrm{~b}$, etc. Bought from Sayle's library in 1800 by Thomas Park (see ff. 1, 3, and Bibliotheca Anglo-Poetica, 1815, p. 328), who used it for his edition (1804) of Nugae Antiquae: see above, artt. 1, 8 (III.), 9, 10. Afterwards belonged successively to Richard Heber (sale-cat. pt. XI., 1836, lot 1336), Thomas Thorpe the bookseller (cat. 1836, no. 1244), and Sir Thomas Phillips (folio cat. 1837 , p.151, no.9474, sale-cat. 1896, lot, 1206). B. Quaritch's cat. 1900 , pt. VII. no. $5811.11_{/: 2}^{1 / 2} \times 75 / \mathrm{s}$ in.

It remains to speak of another ms. $[H$.$] , containing a few$ of the poems, which was commonly known a century ago, but which has since disappeared. This was a ms. which belonged to 'Thomas Hill, the eccentric bibliomaniac. Nott offers no description of this ms., though he alludes to it familiarly as "Mr. Hill's ms.", as does his uncle John Nott in the extant 
pages of notes from his edition of 1812. 1) Of the interlinear pages of one of his copies of the 1812 edition, John Nott copied the variants for Surrey's poems from this ms., though he did not adhere to the early authography, so that we thus have indirect access to the more important variants.

The disappearance of this ms. is puzzling. In 1810, Messrs. Longman bought a large part of Mr. Hill's library, including mss., and used it in the preparation of the Bibliotheca Anglo-Poetica, but this ms. is not cited in that work. As G. F. Nott was working on his edition at the time of the Hill sale, he may have had the ms. in his possession. However, though Nott was so careless about returning mss. that the Duke of Devonshire Ms. was found in the library which he left, the same was probably not true of $H$., or it would have been acquired by the Museum, along with his other mss. As great a mystery attaches to the disappearance of the Harrington Ms. No. ii, the original of $A$. Park used this ms., later Nott used it, and then we hear no more of it. Fortunately Park chanced to record that the writing closely resembles that of $P$., so that we can thus indirectly fix upon its date.

$P$. contains 28 poems; $A$., $18 ; H$., 3 - so far as we can tell -; Harl., 2, and seven verses of a third; $E ., 1 ; D ., 1$; and Harg., the two books of the Aeneid. With the exception of Harg., $P$. and $A$. are then the two most important of the mss. As these two mss. have twelve of Surrey's poems in common, we can determine their relative trustworthiness.

In the long poem, "The sonne hath twyce brought forth the tender green", due to the unfortunate mutilation of A., vs. 10-40 are missing, but in the extant verses, spelling aside, $A$. agrees with $P$. in all but one line, the 44th. Here $A$. reads suck, where $P$. reads sinke. The context is as follows:

for yf I fynde somtyme that I have sought those starres by whome I trusted of the port my sayles do fall and I advaunce right nought as anchord fast my sprites do all resort

1) On the relation of this edition, which was almost totally destroyed by fire, to George Frederick Nott's edition of 1815, see my article in Anglia XXIX pp. $256 \mathrm{ff}$. 


\section{to stand atgaas and sinke in more \& more}

the deadlye harme which [she] doth take in sport.

This poem is also found in $H$. and in $T$., and $H$. agrees with $A$. in reading suck, and $T$., with $P$. in reading sinke. As we shall see later, little reliance is to be placed upon $T$., but it is significant that this is the one instance in which a reading in $H$. differs from the corresponding reading in $P$. In the rest of this poem, and in its two other poems, $H$. exactly agrees with $P$., even to the omission in the present poem of a couplet which is supplied by $T$., and which the rhyme scheme - the terza rima - jnstifies. Nott favors the reading suck, and quotes the following couplet in its support:

Cosi gli affliti e stanchi spiriti mei

a pocò a poco consumando sugge. ${ }^{1}$ )

The citation hardly seems apposite, and the mixed metaphor which results from reading suck is vulgar and absurd. I prefer to read sinke, and to regard the deadlye harme, v. 45., as in apposition with vs. 40-44. The meaning would then be: 'It is fatal for me when my sails fall and my ship sinks, but she only makes light of this, my deadly harme.'

The omission of a couplet in $\boldsymbol{P}$. is characteristic of that ms., for we find similar omissions in several poems. Apparently they were due to the carelessness of the copyist.

$A$. and $P$. agree throughout in the poem "London hast thow accused me". In the poem, "Suche waywarde wais hathe love", aside from the omission of a couplet in $P$., the versions agree in all but the first verse. Here $P$. originally read wailes, which was corrected in a later hand to wais, the reading of $A$. Wais is borne out by the Italian of which this passage is an adaptation: Ingiustissimo Amor! perchè si raro ....2) The remaining poems which these mss. have in common are the translations of the first five chapters of Ecclesiastes, Psalms 88,73 , and 55, and the proems to Psalms 88 and 73 . The proems are alike in the two mss. The versions of the translations differ in a few lines, though in practically every case the reading of $P$. has been corrected by a later hand to agrement

1) Pet. Son. in rita (Ed. of Camerini-Leopardi) 198. 5-6.

2) Ariosto II. 1. 
with the reading of $A$. As both of these mss. were in the possession of the Harringtons, it is likely that $A$. was the very $\mathrm{ms}$. used in the correction of $\boldsymbol{P}$.

The variants in the translations are as follows: Eccles. I. 27 reads in $P$,

I that in dauides seate, sit crowned and reioyce That with my septer rewle the Iewes and teache them with my uoyce

haue serchied long to know, straunge things vnder the sonne. $A$. reads all for straunge, and this reading is correct, for the Latin is, et proposui in animo meo quaerere \& inuestigare sapienter de omnibus quae fiunt sub sole. ${ }^{1}$ ) Again, Eccles. II. 22 reads in $P$.:

to heare faier women sing, sometyme I did reioyce

Rauyshed with ther pleasaunt times, and swetnes of their voyce.

$A$. reads tunes, which the Latin confirms: Feci mihi cantores, \& cantatrices, \& delitias filiorum hominum scyphos, \& vrceos in ministerio ad vina fundenda. Times was probably a clerical error. V. 72 reads in $P$.:

the gladsome dayes we passe, to serche a simple gaine

The quiete nights with broken slepes, to fead a resteles brayne.

$A$. reads the broken sleapes, but the Latin here bears out $P$.: nec per noctem mente requiescit. In Eccles. IV. 34, P. omits thre fould in the verse

The single twyned cordes, may no suche stresse indure as cables brayded [thre fould] may, to gether wrethed swer.

The scansion requires the word, and it is found in the original: funiculus triplex difficile rumpitur. Probably the omission of the word is simply another instance of clerical carelessness. For Eccles. V. 17, P. reads

With fayned words and othes, contract with god no gyle suche craft returns, to thy nown harme, and doth thy self defile

And thoughe the myst of sinne, perswad such error light therby yet ar, thy owtward works, all dampned in his sight.

') Ed. of Lugduni, 1536. 
$A$. reads worls for words. Words I take to be the correct reading, and it was probably altered to works by one who did not know the Latin, and thought that the "works" in v. 20 found its antecedent idea in v. 17. The Latin is as follows: Ne dederis os tuum vt peccare facias carnem tuam, necque dicas coram angelo. Non est prouidentia, ne forte iratus deus contra sermones tuos dissipet cuncta opera manuun tuarum. In v. $32, P$. omits another word which the scansion requires.

Ps. 88. 24 reads in $P$.:

nor suche sett forth thy faith as dwell in the land of dispaire.

$A$. reads praise instead of faith; neither is a close translation of the Latin, but $P$. is to be preferred: Nunquid narrabit aliquis .... veritatem tuam in perditione? In v. 27 , on the other hand, the reading of $A$. is to be preferred. The verse is as follows:

nor blasted may thy name be by the mouth of those whome death hath shitt in sylence so as they may not disclose. In reading blazed rather than blasted, $A$. is nearer the Latin, which runs: Nunquid cognoscentur in tenebris mirabilia tua? Finally, in Ps. 55 the reading of $A$. is right for one muted passage, and $P$. for another. Vs. 20-21 read in $P$.:

for though myne ennemyes happ had byn for to preuaile

I cold not have hidd my face from uenym of his eye. $A$., on the other hand, reads:

for thoughe myne ennemyes happ had bene for to prevaile I coulde have hydd my face from venome of his eye.

The Latin reads: Quoniam si inimicus maledixisset mihi, sustinuissem utique, and the whole burden of the passage is that the Psalmist could have endured the enmity of a foe, but not the disloyalty of a friend. In v. 26, however, $P$. clearly has the best of it in reading,

such soden surprys quicke may them hell deuoure, for the variant in A.: may hym self devoure, is not in keeping with the original: Veniat mors super illos, \& descendant in infernum viuentes.

So much for the comparison of $P$. and $A$. The two mss. prove to be much alike, and to about equally trustworthy, 
with the balance slightly in favor of $A$. They should now be compared with $E$, the ms. containing Wyatt's autograph poems, in order to find how closely these two Elizabethen mss. keep to the earliest readings.

$P$. and $E$. have one of Surrey's poems in common, and five of Wyatt's. In the Surrey poem, 'The great Macedon that out of persy chased', save for spelling the versions agree throughout. In the Wyatt poems the versions of $P$. are found to be tolerably faithful, by no means unaltered, but not taking those daring liberties that one finds in $T$. The comparison of two or three of the poems will demonstrate this. The poem, 'The wandering gadlyng in the sommer tyde', reads as follows in $E$.:

The wandering gadlyng in the sommer tyde | that fyndes the Adder | with his recheles fote | startes not dismayd, so soudenly a side | as Jalous dispite did: tho there war no bote | when that he sawe me sitting by her side | that of my helth $\mid$ is very croppe \& rote. it pleased me then to have so fair a grace 1 to styng that hert, that would have my place. ')

For verse $4, P$. reads:

as did gelosy tho ther were no boote, and for verses $7-8$ :

yt pleased me to have so faire a grace

to styng the wight that wold have my place.

Verses 4 and 7 are merely altered for the sake of the meter, and by none of the changes is the meaning affected. Verse 5 of the poem 'Venemous thornes that ar so sharp \& kene' reads

ffyre yat purgeth allthing yat is vnclene. ${ }^{2}$ )

In $P$. the line is altered to,

the fier eke that all consumeth cleene.

Here the meaning is actually changed. Aside from this verse, the two versions agree. Of the satire 'Myne owne J. P. sins you delight to knowe', the version in $P$. shows four alterations, aside from the occasional change in the tense of a verb, or in

1) Anglia 17, 479. $\quad$ 3) Ang. 17, 511 . 
the arrangement of the words in a verse, though it should be observed that the first fifty verses are wanting in $E$. In verse $55, P$. changes nyght \& daye to day and night, $\left.{ }^{1}\right)$ though the terza rima requires the former. Verse 57 , which reads,

none of these poyntes would ever frame in me my wit is nought I cannot lerne the waye,

is altered to to way. Other variants occur in verses 96 and 99 . E. reads:

Nor flaunders chiere letteth not my sight to deme of black and white nor taketh my wit alwaye with bestlynes they beest do so esteme Nor I ame not where Christe is geven in pray for mony poison and traison at Rome a comune practise vsed nyght and daie.

In $96, P$. reads the beastes, and in 99 a comon place.

These comparisons show that $P$. does not give us the poems as they came from the pens of the authors, and yet that it is tolerably trustworthy.

$\boldsymbol{E}$. and $A$. have sixty poems in common, and in these sixty poems I find in $A$. thirty-four instances of alterations that have changed the meaning of a passage. Some of these are unintentional, due to careless copying; others, to a desire to better the meaning. I will illustrate the latter. Verses $1-6$ of the poem 'My galy charged with forgetfulnes' read in $E$. as follows:

My galy charged with forgetfulnes

thorrough sharpe sees in wynter nyghtes doeth pas

twene rock \& rock \& eke myn ennemy alas,

that is my Lords sterith with cruelnes.

and every owre a thought in redines.

as tho that deth were light in suche a case. ${ }^{2}$ )

$A$. alters verse 4 to read, stirreth up with cruelness, and verse 6 to read, that deth weare life. The Italian shows, even if we had not the testimony of Wyatt's handwriting, that the version in $\mathrm{E}$. is the right one. In two instances lines have been changed to correct faulty rhymes. Thus the verse,

$i$ in the lord have ever set my trust, ${ }^{3}$ )

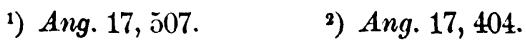

3) Ps. 130, 20; Ang. 17, 441. 
is changed to read,

I in the Lord have sett my confydence, and by this change the regularity of the terza rima, which Wyatt had violated, is established.

Besides these alterations which affect the meaning, in almost every poem verses are rearranged, or slightly modified, to secure metrical regularity. To give a few illustrations:

$E$. Ther was never ffile half so well filed, $\left.{ }^{1}\right)$

$A$. Was never ffyle yet half so well yfyled.

$E$. that though / tymely deth hath ben so slo, ${ }^{2}$ )

$A$. that thoughe my tymelye

$E$. he toke me from rest: \& sett me in errour, ${ }^{3}$ )

$A$. Me from my rest he toke, and sett in errour.

On the whole, $A$. shows itself to be tolerably faithful to the original. In fact, next to $E$. it is the most trustworthy of the Wyatt mss., for on comparison I find that though $D$. is a pre-Elizabethan ms., it is less cautious in emendation than is $A$. It is reasonable to suppose that $A$. departs even less from the original version of Surrey's poems, for there was less temptation to emendation, as the metre was more regular and the meaning less often in doubt.

The discovery of $P$. completes the evidence against Tottel's Miscellany; it is shown to be as unreliable for Surrey's poems as Professor Flügel's transcripts have shown it to be for Wyatt's. There is scarcely a poem that is left unchanged, and some have been almost rewritten throughout. I will give only one illustration from the Tottel, as the pages which follow furnish opportunity for further comparison. The sonnet, 'I neuer saw youe madam laye aparte', reads as follows in $P$.:

I neuer saw youe madam laye aparte your cornet black in colde nor yet in heate sythe first ye knew of my desire so greate which other fances chaced cleane from my harte whiles to my self I did the thought reserve that so vnware did wounde my wofull brest pytie I saw within your hart dyd rest

1) Ang. 17, 289.

2) Ang. 17, 279.

3) Ang. 17, 278. 
but since ye knew I did youe love and serve your golden treese was clad alway in blacke

all that withdrawne that I did crave so sore so dothe this cornet governe me a lacke In sommeres sonne in winter breath of frost of your faire eies whereby the light is lost. H. S.

Tottel's version shows the following remarkable differences:

I neuer sawe my Ladye laye apart

Her cornet blacke, in colde nor yet in heate, Sith first she knew my griefe was growen so great, Which other fansies driueth from my hart That to my selfe I do the thought reserue, The which vnwares did wounde my wofull brest:

But on her face mine eyes mought neuer rest, Yet, sins she knew I did her loue and serue Her golden tresses cladde alway with blacke, Her smilyng lokes that hid thus euermore, And that restraines whiche I desire so sore. So dothe this cornet gouerne me alacke:

In somer, sunne: in winters breath, a frost:

Wherby the light of her faire lokes I lost. ')

The sonnet is a translation of Petrarch, Ballad $I$, which reads as follows:

Lassare il velo o per Sole o per ombra,

Donna, non vi vid' io,

Poi che 'n me conosceste il gran desio

Ch'ogni altra voglia d'entr'al cor mi sgombra.

Mentr'io portava i be' pensier celati

C'hanno la mente desiando morta, Vidivi di pietate ornare il volto:

Ma poi ch' Amor di me vi fece accorta, Fur i biondi capelli allor velati, E l'amoroso sguardo in se raccolto. Quel ch' i' più desiava in voi, m'è tolto; Si mi governa il velo, 
Che per mia morte, ed al caldo ed al gelo, De' be' vostr' occhi il dolce lume adombra.

In every point of difference $P$. keeps to the Italian, and $T$. departs from it. Thus in $P$., the poem is addressed in the second person; desire, v. 3, translates desio; the first sentence closes with v. 4 ; whiles, v. 5 , translates mentre; and v. 7 is a literal translation.

Although Harl. contains only two of the poems and a fragment of a third, it gives the sole version of one of these, and the only satisfactory version of the other. The few poems from Wyatt which it contains show that it is even closer to the readings of $E$. than is $A$. In only three instances is a word substituted, and there is no attempt to improve the lines by those slight modifications so common in $A$.

$H$., as already noted, is almost identical with $P$. As Harg. is independent of these mss., it will be reserved for a later number, where a discussion of the ms. will accompany a transcript of the fourth book of the Aeneid.

In conclusion, we have in $P$., $A$., and Harl., three mss. which furnish the larger part of Surrey's poems, in fairly correct versions, that are much more reliable than Tottel's Miscellany.

The following pages offer a transcript of these poems. Where a poem occurs in more than one ms., all of the variants, even those in spelling, are given, though from $T$. only those are given which affect the meaning.

\section{Poems in Add. Ms. 36529.}

[f.50a] The sonne hath twyse brought forthe the tender grene, and cladd the yerthe in livelye lustynes,

Ones have the wyndes the trees dispoyled clene, and now agayne begynnes their cruelnes;

5] sins I have hidd vnder my brest the harme that never shall recover helthfulnes

the wynters hurt recovers with the warme; the perched grene restored is with shade what warmth alas may sarve for to disarme

10] the froosyn hart that my inflame hath made? what colde agayne is hable to restore my freshe grene yeres that wither thus \& faade? 
THE MS. POEMS OF HENRY HOWARD, EARL OF SURREY. 287

alas I see nothinge to hurt so sore

but tyme somtyme reduceth a retourne;

15] yet tyme my harme increseth more \& more, and semes to have my cure allwayes in skorne; straunge kynd of death, in lief that I doo trye at hand to melt farr of in flame to bourne [and like as time list to my cure aply

20] so doth eche place my comfort cleane refuse.] eche thing alive that sees the heaven with eye with cloke of [n]ight maye cover and excuse him self from travaile of the dayes vnrest save $I$ alas against all others vse

25] that then sturres vpp the torment of my brest to curse eche starr as cawser of my faat and when the sonne hath eke the darke represt and brought the daie yet doth nothing abaat the travaile of my endles smart \& payne

30] ffor then as one that hath the light in haat I wishe for night more covertlye to playne and me withdrawe from everie haunted place lest in my chere my chaunce should pere to playne and with my mynd I measure paas by paas

35] to seke that place where I my self hadd lost that daye that I was tangled in that laase in seming slacke that knytteth ever most but never yet the trayvaile of my thought of better state could catche a cawse to bost

40] for yf I fynde somtyme that I have sought those starres by whome I trusted of the port my sayles do fall and I advaunce right nought as anchord fast my sprites do all resort to stand atgaas and sinke in more \& more

45] the deadlye harme which [she] doth take in sport $[50 b]$ loo yf I seke how I do fynd my sore and yf I flye I carrey with me still the venymd shaft which dothe his force restore by hast of flight and I maye playne my fill

50] vnto my self oneles this carefull song prynt in your hert some percell of my will for $I$ alas in sylence all to long 
of myne old hurt yet fele the wound but grene rue $0[\mathrm{n}]$ me lief or elles your crewell wrong shall well appeare and by my deth be sene. ffinis. H. S.

Notes on the text: 29 might. - 28 yet replaced by it above, later hand. -44 the $\mathrm{t}$ in atgaas seems to replace some earlier letter. - 45 she inserted by later hand. -52 or.

The poem is preceded by the following title in a later hand: 'Severall Poems by the right Honorable Henry Earle of Surrey, unjustly put to death by Henry ye 8 th.' As announced in a note on f. $49 b$, Dr. Percy has prefixed an ${ }^{*}$ to such of the following lyrics in $P$. as are also to be found in the printed ed. of 1557 . He has also numbered them.

Found also in $A$. [24a] and $H$. [115].

Variants in $A .: 1$ the tender grene wanting. -2 earthe, lyvely lustinesse. - 3 once, treese, clene. - 4 crewelnesse. - 5 synce, hydd. 6 healthfullnesse. -8 pearched greene. - 9 warmthe, serve. - vs. 1040 wanting. - 43 anchorde, sprytes. - 44 at gaze, suck. - 45 whiche, doth, sporte. - 46 Lo, seeke, fynde. - 47 carrye. - 48 venomde shafte, doth. - 49 flyght. - 50 vnto, vnlesse. - 51 print in your harte some percell of good will. - 52 scylence. - 53 olde, feele the wownd but greene. - 54 Rew, lyfe, ells, wronge. - 55 deathe. - Vs. 1, 46, 54, begin with caps.

Variants in $H$. : 19-20 wanting. - 25 stirs. - 44 at gaze and suck.

Variants in T. [1.]: 1 his tender. - 4 new. -8 the shade. 10 mine. - 13 hath. -14 time in time. -15 in time. $-17 \mathrm{kinds}$. 19-20 the couplet as supplied in the text. - 21 all thing. - 22 night. -23 it self. -25 torments. -26 to curse. -27 opprest. -28 it doth. - 29 trauailes. - 33 lest by my chere my chance appere to playn. 34 in my mind. - 35 the place. - 36 the lace. -44 agazed. -51 of my tene.

[The Italian sources of this and the following poems may be found in Nott's edition, and Koeppel's Studien zur Geschichte des engl. Petrarchismus, in Roman. Forschungen 5.]

[51 a] So crewell prison howe could betyde alas as prowde wyndsour, where $I$ in lust \& ioye with a kinges soon my childishe yeres did passe in greater feast then Priams sonnes of Troye

5] where eche swete place retournes a tast full sowre the large grene courtes, where we wer wont to hove with eyes cast vpp vnto the maydens towre and easye sighes such as folke drawe in love the statelye sales, the Ladyes bright of hewe 10] the daunces short, long tales of great delight 
with wordes and lookes, that Tygers could but rewe where eche of vs did plead the others right the palme playe where dispoyled for the game with dased eyes oft we by gleames of love

15] have mist the ball and got sight of our dame to bayte her eyes which kept the leddes above the graveld ground with sleves tyed on the helme on fomynge horse with swordes and frendlye hertes with chere as thoughe the one should overwhelme

20] where we have fought $\&$ chased oft with dartes with sylver dropps the meades yet spredd for rewthe In active games of nymblenes and strengthe where we dyd strayne, trayled by swarmes of youthe our tender lymes that yet shott vpp in lengthe

25] the secret groves which oft we made resound of pleausaunt playnt, \& of our ladyes prayes recording soft, what grace eche one had found what hope of spede what dred of long delayes the wyld forest, the clothed holtes with grene

$30]$ with raynes avald, and swift ybrethed horse with crye of houndes and merey blastes bitwen where we did chace the fearfull hart a force the voyd walles eke that harbourde vs eche night wherwith alas revive within my brest

35] the swete accord such slepes as yet delight the pleasaunt dreames the quyet bedd of rest the secret thoughtes imparted with such trust the wanton talke, the dyvers chaung of playe the frendshipp sworne eche promyse kept so iust

40] wherwith we past the winter nightes awaye. and with this thought the blood forsakes my face the teares berayne my chekes of dedlye hewe the which as sone as sobbing sighes alas

[51.b] vpsupped have thus I my playnt renewe

45] O place of blys renewer of my woos geve me accompt wher is my noble fere whome in thy walles thow didest eche night enclose to other lief, but vnto me most dere eache alas that dothe my sorowe rewe 50 ] retournes therto a hollowe sound of playnt Anglia. N. $F$. XVII. 
thus I alone where all my fredome grew In pryson pyne with bondage and restraynt and with remembraunce of the greater greif To bannishe the lesse I fynde my chief releif ffinis. $\mathrm{H}$. H.

Note on the text: 54 in releif, it looks as if the writer stcrted to make $a \mathrm{y}$ and then altered it to $\mathrm{i}$.

Found also in $H$. [117]; no variants.

Variants in T. [13]: 9 seates. - 16 leads. - 19 though one should another whelme. -23 trayned with. -29 holtes. -32 of force. -33 wide vales eke. - 40 night. 47 doest. - 49 Eccho.

[52a] 1] London, hast thow accused me Of breche of lawes the roote of stryfe, within whose brest did boyle to see (so fervent hotte) thy dissolute lief

5 5 that even the hate of synnes that groo within thy wicked walles so rife ffor to breake forthe did convert soo that terrour colde it not represse the which by wordes syns prechers knoo

10] what hope is le[f]t for to redresse by vnknowne meanes it liked me my hydden burden to expresse wherby yt might appere to the that secret synn hath secret spight

15] ffrom Iustice rodd no fault is free but that all such as wourkes vnright In most quyet are next ill rest In secret sylence of the night this made me with a reckles brest

20] to wake thy sluggardes with my bowe A fygure of the lordes behest whose scourge for synn the sc[r]eptures shew that as the fearfull thonder clapp by soddayne flame at hand we knowe

25] of peoble stones the sowndles rapp the dredfull plage might mak the see of goddes wrath that doth the enwrapp that pryde might know from conscyence free how loftye workes may her defend 
$30]$ and envye fynd as he hath sought how other seke him to offend and wrath tast of eche crewell thought the iust shapp hyer in the end and ydell slouthe that never wrought

35 ] to heven hys spirite lift may begyn $\&$ gredye lucre lyve in drede to see what haate ill gott goodes wynn the lechers ye that lustes do feed perceve what secrecye is in synne

40] and gluttons hartes for sorow blede awaked when their faulte they fynd In lothsome vyce eche dronken wight to styrr to godd this was my mynd thy wyndowes had don me no spight

[52b] 45] but prowd people that drede no fall clothed with falshed and vnright bred in the closures of thy wall but wrested to wrathe in fervent zeale thow hast to strief my secret call

50] endured hartes no warning feale Oh shameles hore is dred then gone by suche thy foes as ment thy weale Oh membre of false Babylon the shopp of craft, the denne of ire

55] thy dredfull dome drawes fast vppon thy martyres blood by swoord \& fyre In heaven \& earth for Iustice call the lord shall here their iust desyre the flame of wrath shall on the fall

$60]$ with famyne and pest lamentablie stricken shalbe they lecheres all they prowd towers and turretes hye enmyes to god beat stone from stone thyne Idolles burnt that wrought iniquitie

65] when none thy ruyne shall bemone but render vito the right wise lord that so hath iudged Babylon Imortall praise with one accord ffynis H. S. 
Note on the text: 10 lest.

Found also in $A$. [25a], with the following variants: 2 breache. 4 no brackets; hote thye, lyf. -5 synns. -6 thie, walls, ryfe. -7 for, so. -8 could. -9 whiche, synce preachers. -10 left. -11 unknowen, lyked. - 12 bourden. - 13 it, appeare. - 14 secreat synne, secreat. 15 justice rodde, faulte. - 16 suche, workes unright. - 17 moste, nexte.

- 18 secreat scylence. - 19 recklesse. - 20 thie sluggards. - 21 Lordes.

- 22 skourdge, synne, scryptures. - 23 fearefull. - 24 suddayne. 25 sowndlesse. -26 ye, plague. - 27 dothe, thee. -28 conscience. 29 loftie. - 32 eache. - 33 just shape. - 34 ydle slowth. - 35 hearen his. - 36 greedye lukre, dreed. - 37 hate, gote. - 38 letchers, feede. 39 perceave, secreasye, syn. - 40 sorrow bleede. - 41 fynde. -42 eache droncken. - 43 God, mynde. - 44 thie windowes hadd done. - 45 dread. - 49 strif, secreat. - 50 warninge feele. - 51 shamelesse whore, dread, gon. -52 thie, meantt thie. -53 falce. -54 crafte, den, yre. -55 dreadfull. -56 thie martyres, sword. - 57 justice. -58 heare. -59 flambe, wrathe. - 60 lamentably. - 61 stryken shall be thie letchers. - 62 thic, turrettes. -63 God. -64 Idolls. -66 unto, rightuous Lord. -67 judged.

- 68 Immortall prayse, accorde.

Vs. 1, 51, 53, 68, begin with caps.

Not found in $\mathrm{T}$.

[53a]

1] Suche waywarde [wais] hath love that moste parte in discorde

our willes do stand wherby our hartes but seldom dooth accorde

Disceyte is his delight and to begyle and mocke The symple hertes which he doth stryke with froward dyvers stroke

5] he cawseth hertes to rage with golden burninge darte and doth alaye with ledden cold agayne the tothers harte hot gleames of burning fyre \& easye sparkes of flame In balaunce of vnegall weight he pondereth by ame ffrom easye fourde where I might wade \& passe full well

10] he me withdrawes and doth me drive into the darke diep well

and me withholdees where I am cald and offerd place and wooll that still my mortall foo I do beseche of grace he lettes me to pursue a conquest well nere woon to follow where my paynes wer spilt or that my sute begune

15] lo by these rules I know how sone a hart can turne from warr to peace from trewce to stryf and so again returne 
I knowe how to convert my will in others lust of litle stuff vnto my self to weyve a webb of trust and how to hide my harme with soft dissembled chere 20] when in my face the paynted thoughtes wolde owtwardlye appere

I knowe how that the blood for sakes the faas for dredd and how by shame it staynes agayne the chekes with flaming redd

I knowe vnder the grene the Serpent how he lurckes the hamer of the restles forge I know eke how yt workes

25] I know and can be roote the tale that I wold tell but ofte the wordes come forth a wrye of hym that loveth well

I know in heat and cold the lover how he shakes In singinge how he can complayne, in sleaping how he wakes

to languishe without ache sickles for to consume

30] a thousand thinges for to devyse resolving all hys fume land thoughe he lyke to seehis ladies face full sore suche pleasure as delightes his eye doth not his health restore]

I know to seke the tracke of my desyred foo and feare to fynd that I do seke but chefelye this I know

35] that lovers must transforme into the thing beloved and live alas (who colde beleve) with spryte from lief removed

I know in hartye sighes and lawghters of the splene at ones to chaunge my state my will \& eke my colour. clene

I know how to disceyve my self withouten helpp

40] and how the lyon chastysed is by beating of the whelpp In standing nere my fyer I know how that I frese ffarr of to burn, in both to wast \& so my lief to lese I know how love doth rage vppon the yeldon mynd how small a nett may take \& mashe a hart of gentle kynd

45] which seldome tasted swete do seasoned heaps of gall revyved with a glyns of grace olde sorowes to let fall the hidden traynes I know \& secret snares of love how sone a loke may prynt a thought that never will remoue 
that slipper state I know those sodayne tournes from welthe

50] that doutfull hope that certayne woo \& sure dispaire of helthe.

Notes on the text: 1 wais replaces wailes, later hand - 12 do inserted above, same hand - 30 his crossed out and replaced by in, later hand. - 36 the e of colde is doubtful.

Found also in A. [26a], with the following variants: 1 wayward wayes, part. -2 wills doth, whearby, seeldome doth. - 3 Disceite begeuyle. 4 hartes whiche. -5 and causeth hartes, goolden. -6 leadden colde. 7 hotte, bourninge. -8 waight, ponderith. -9 forde wheare. -10 dothe, dryve, deepe. - 11 me wanting, witholdes, calde, offred. - 12 will, foe. - 13 and for he, neare woonne. - 14 wheare, weare, er, begonne. 15 theise. - 16 truce, strif, agayne retourne. - 18 lytle stuffe unto myself, weive, webbe. - 19 hyde, softe dissemblid cheare. - 20 appeare. 21 bloode, face, dead. - 22 bye, cheekes. - 23 greene. - 24 hammer, restlesse, it. -25 roate. - 26 forthe awrye. - 27 colde. - 28 singing, sleapinge. -29 Sicklesse. -30 thowsand, in for his. $-31-32$ the couplet inserted in the text. - 33 foe. - 34 fynde, seeke, chieflye. - 35 lover, beloved. - 36 lyve, whoe could belyve, spirit, lyf removed. - 37 hartie, spleene. - 38 coulour cleene. - 39 disceave my self, helppe. - 40 Lyon, whelppe. - 41 neare, the for my, freese. - 42 farr, bournne, bothe, waste, my self, leese. - 43 a yolden mynde. - 44 an hart, kynde. - 45 whiche seeldome, heapes. -46 glyntt. -47 thos, trains, secreat. - 48 sone, looke, print athought, remove. - 49 sodaine turnes, wealth. - 50 doubtful, certaine woe, health.

The caesura is marked throughout. The following verses, in addition to those beginning with the first personal pronoun, begin with caps.: 1, 3, 15, 29.

Variants in T. [6]: 1 waies. -2 doe. -4 whom. -5 He makes the one to rage. -6 other. - 10 a depe dark hel. - 11 And me withholdes. - 12 willes me that my. - 14 were lost. - 15 So, may turnc. 17 content my self. -19 harmes, dissembling. -24 wote. -30 in fume. - 31-32 the couplet:

and though he list to se his ladies grace ful sore,

Such pleasures as delight the eye doe not his health restore.

- 36 (alas who would beleue?). - 39 with others help. - 42 I burne, I wast, I leze. - 43 a yelding. - 45 Or els with seldom swete to season. - 48 wil printe. - 49 the slipper, the sodain. - 50 The doubtful, the certain.

[53b] 1] As oft as I behold and see the soveraigne bewtie that me bound the ner my comfort is to me alas the fressher is my wound 
5] As flame dothe quenche by rage of fier and roounyng streames consumes by raine so doth the sight that $i$ desire apeace my grief and deadly payne

Like as the flee that seethe the flame

10] and thinkes to plaie her in the fier that fownd her woe and sowght her game whose grief did growe by her desire

When first I saw theise christall streames whose bewtie made this mortall wound

15] I litle thought with in these beames so sweete a venvme to have found

Wherein is hid the crewell bytt whose sharpe repulse none can resist and eake the spoore that straynith eche wytt

20] to roon the race against his list

But wilful will did prick me forthe blynd cupide dyd me whipp \& guyde force made me take my grief in worthe my fruytles hope my harme did hide

25] I fall and see my none decaye as he that beares flame in his brest fforgetes for payne to cast awaye the thing that breadythe his vnrest

And as the spyder drawes her lyne 30] with labour lost I frame my sewt the fault is hers the losse ys myne of yll sown seed such ys the frewte.

Note on the text: 19 straynith altered from (?) straynneth.

Variants in T. [24]: stanzas 3,5 , and 8 are lacking, but the following stanza occurs after the stanza 'But wilfull will ...':

As cruell waues full oft be found

Against the rockes to rore and cry :

So doth my hart full oft rebound Ageinst my brest full bitterly.

- 13 First when, those. - 14 my mortall. - 15 within her. -22 And blinde Cupide did whippe. -27 in paine to put. -28 mine vnrest. 
[54a] 1] When youthe had ledd me half the race, That Cupides scourge did make me rune, I loked backe to mete the place ffrom whence my werye course begune.

5] And then I sawe how my desyre by ill gydyng had let my waye whose eyes to greedye of their hire had lost me manye a noble praye

FFor when in sightes I spent the daye, 10] and could not clooke my grief by game, their boyling smoke did still bewraye the fervent rage of hidden flame:

And when salt teares did bayne my brest where love his pleasaunt traynes had sowne

15] the brewt therof my frewt opprest, or that the bloomes were sprunge $\&$ blowne.

And where myne eyes did still pursewe the flying chace that was their quest their gredye lookes did oft renewe 20] the hydden wounde within my brest

When everye looke these cheekes might stayne from dedlye pale to flaming redd by owtward signes apperyd playne the woo wherwith my hart was fedd

25] But all to late love learneth me to paynt all kynd of coloures newe to blynde their eyes that elles should see my sparskled chekes with Cupydes hewe

And now the covert brest I clayme

30] that worshipps Cupyd secretlye and nourysheth hys sacred flame ffrom whence no blasing sparckes do flye. ffinis. H. S.

Notes on the text: 9 sighte would be preferable, but the final character is the usual $a b b$. for es. -27 the e of blynde is doubtful. 
THE MS. POEMS OF HENRY HOWARD, EARL OF SURREY. 297

Variants in T. [5]: 2 me causde. -6 misguiding me had led the way. - 7 Mine eyen. - 8 Had made me lose a better. - 9 sighes. 10 with game. - 11 The boiling smoke. - 12 The persaunt heate of secrete flame. - 13 doe bayne. - 15 Her bewty hath the fruites. 22 glowing red. -24 wherin.

1] Marshall the thinges for to attayne the happy life be thes I fynde the riches left, not got with payne the frutfull grownd the quyet mynde

5] the equall freend no grudge nor stryf no charge of rule nor governance without disease the helthfull life the howshold of contynvance the meane dyet no delicate fare

10] wisdom joyned with simplicitye the night discharged of all care where wyne may beare no soveranty the chast wife wyse without debate suche sleapes as may begyle the night

15] Contented with thyne owne estate neyther wisshe death nor fear his might. H. S.

Notes on the text: 8 contynvance replaces an original contenaunce, crossed out; same hand. - 12 soveranty replaces soventy crossed out; same hand.

Variants in T. [27]: 1 that do. -5 no strife. - 10 Trew wisdom joyned with simplenesse. -12 the wit may not oppresse. -13 The faithful wife, without. - 16 No wish for death, ne.

[55a] 1] Ffrom Tuscan cam my ladies worthi race faire fflorence was sometime her auncient seate the westorne Ile (whose pleasaunt showre doth face wylde Chambares cliffes) did geve her lyvely heate

5] ffostred she was with mylke of Irishe brest her Syer [an] erle, hir dame, of princes bloud from tender yeres in britaine she doth rest with a kinges child where she tastes gostly foode honsdon did furst present her to myn eyen

10] bryght ys her hew and Geraldine shee highte Hampton me tawght to wishe her furst for myne 
and windesor alas doth chace me from her sight bewty of kind, her vertues from a bove happy ys he, that may obtaine her love.

H. S.

Notes on the text: 6 an inserted before erle, different hand. 11 furst inserted, same hand -13 of kind replaces an original her mate, or her mace.

Variants in T. [9]: 6 an Erle. - 8 no article, tasteth costly. 13 Her beauty. 14 can.

1] When windesor walles sustained my wearied arme my hand, my chyn, to ease my restles hedd ech pleasaunt plot revested green with warm the blossomed bowes with lustie veare yspred

5] the flowred meades the weddyd birdes so late myne eyes discouered. than did to mynd resort the Ioily woes the hateles shorte debate tha rakhell life that longes to loves disporte wherwith alas myne hevy charge of care

10] heapt in my brest brake forth against my will and smoky sighes that over cast the ayer my vapored eyes such drery teares distill the tender spring to quicken wher thei fall and I have bent to throwe me downe with all. H. S.

Notes on the text: 3 originally plat. -4 with lustie replaces which lively, same hand. -7 the i of Ioily inserted - 13 before distill stands doth crossed out. - 14 have alt. from half, hand uncertain.

Variants in $T$. [11]: 6 discouer: and to my minde. - 14 halfebent.

[55b] 1] I neuer saw youe madam laye aparte your cornet black in colde nor yet in heate sythe first ye knew of my desire so greate which other fances chaced cleane from my harte

5] whiles to my self I did the thought reserve that so vnware did wounde my wofull brett pytie I saw within your hart dyd rest but since ye knew I did youe love and serve your golden treese was clad alway in blacke 10] .

all that withdrawne that I did crave so sore 
TEH MS. POEMS OF HENRY IIOWARD, EARL OF SURREY.

So doth this cornet governe me a lacke

In someres sone in winter breath of frost

of your faire eies whereby the light is lost.

H. S.

Tottel's version will be found in the Introduction, p. 285.

1] Love that doth raine and liue within my thought and buylt his seat within my captyve brest clad in the armes wherein with me he fowght oft in my face he doth his banner rest

5] but.she that tawght me love and suffre paine my doub[t]full hope \& eke my hote desire with shamfast looke to shadoo and refrayne her smyling grace convertyth streight to yre And cowarde love then to the hart apace

10] taketh his flight where he doth lorke and playne his purpose lost and dare not shew his face for my lordes gilt thus fawtles byde I payine yet from my Lorde shall not my foote remove sweet is the death that taketh end by love.

H. S.

Note on the text: 6 line inserted in margin, same hand.

Variants in T. [8]: 1 that lineth and reigneth in. -2 That built. 7 cloke. - 10 whereas he lurkes and plaines. - 12 paynes. - 14 his deatb, takes his.

[56a] 1] In Cipres springes (wheras dame venus dwelt) a well so hote, that who so tastes the same were he of stone as thawed yse shuld melt and kindled fynde his brest with secret flame

5] whose moist poison dissolved hath my hate this creping fier my cold lymmes so oprest that in the hart that harbred fredom late endles dispaire long thraldom hath imprest one eke so cold in froson snow is found

10] whose chilling venume of repugnant kind the fervent heat doth quenche of cupides wound and with the spote of change infectes the mynd 
where of my deer hath tasted to my payne my service thus is growne into disdayne.

H. S.

Note on the text: 9 snow replaces sone, same hand.

Variants in $T$. [9]: 4 fired flame. -9 An other so colde in frozen yse.

1] The greate Macedon that out of persy chased Darius of whose huge powre all Asia range in the riche arke yf hommers rymes he placed who fayned gestes of heathen princes sange

5] what holie grave, what worthye sepulture to wyates spalmes should christians than purchace where he doth painte the lively fayth and pure the stedfast hope the sweet returne to grace of Iust David by perfect penitence

10] where rulers may see in a myrrour clere the bytter frute of false concupicence how Iurye bowght vryas death full deere In princes hartes godes scource yprinted deepe mowght them awake out of their synfull sleepe.

H. S.

Notes on the text: 9 snow replaces orig. sone, same hand. 13 pyrinted altered from imprinted, same hand.

Found also in $E$. [85b], with the following. variants: 1 great, Perse chasyd. -2 power, Asy Rang. -3 if Homers, placyd. -4 Hethen Prynces sang. -5 holly, wourthy. -6 Wyates Psalmes shuld (final e crossed out) Christians then purchace. -7 Wher, dothe paynte, lyvely faythe. -8 hoope, swete. - 9 iust Dauyd, parfite penytence. - 10 Rewlers, se. -- 11 bitter frewte, concupiscence(s crossed out in different ink). - 12 Iewry bought Vryas deathe, dere. - 13 Prynces, goddes, yprynted depe. - 14 Myght, slepe. - Every verse begins with a cap.

Variants in $T$. [28]: 3 dan Homers. - 13 imprinted. -14 Ought.

[56b] 1] In the rude age when Scyence was not so rife If Jove in crete and other where they taught Artes to reverte to profyte of our lyfe wan after deathe to have their temples sought

5] If vertue yet in no vnthankfull tyme fayled of some to blast her endles fame a goodlie meane bothe to deter from cryme and to her steppes our sequell to enflame 
In deyes of treuthe if wyatte's frendes then waile

10] (the onelye debte that ded of quycke may clayme)

That rare wit spent employde to our avayle where Christe is tought deserve they monnis blame His livelie face thy brest how did it freate? whose Cynders yet with envye doo the eate H. S.

Note on the text: 1 the, so, crossed out.

Variants in $T$. [218]: 1 knowledge was not rife. - 2 other were. 3 conuert. -- 4 Wende. -5 yet no voyde. -12 we led to vertues traine. -13 brestes. -14 they do eate.

1] Thassyryans King in peas with fowle desyre And filthye lustes that staynd his regall harte In warr that should sett pryncelye hertes a fyre vaynquyshd dyd yelde for want of marcyall arte

5] The dent of swordes from kysses straunge and harder then hys ladyes syde his targe from glotton feastes to sowldyers fare a chaunge his helmet far aboue a garlandes charge who scace the name of manhode dyd retayne

10] Drenched in slouthe a womanishe delight Ffeble of sprete vnpacyent of payne when he hadd lost his honour and hys right Prowde tyme of welthe, in stormes appawld with drede murdred hym self to shew some manfull dede H. S.

Variants in T. [30]: 1 Thassirian. -3 on fire. -4 Did yeld, vanquisht. - 5 dint. - 11 impacient.

1] Yf he that erst the fourme so livelye drewe of venus faas tryvmpht in paynteres arte Thy father then what glorye did ensew By whose pencell a goddesse made thow arte 5] Touchid with flame, that figure made some rewe And with her love surprysed manye a hart There lackt yet that should cure their hoot desyer Thow canst enflame and quenche the kyndled fyre H. S.

Found also in $H$, with the following variant: 3 shall ensue.

Not in $T$. 
[57a] 1] Set me wheras the sonne, dothe perche the grene or whear his beames, may not dissolue the Ise In temprat heat, wheare he is felt and sene with prowde people, in presence sad and wyse

5] Set me in base, or yet in highe degree in the long night, or in the shortyst day in clere weather, or whear mysts thikest be in lofte yowthe, or when my heares be grey set me in earthe, in heauen or yet in hell

10] in hill, in dale, or in the fowming floode Thrawle, or at large, aliue whersoo I dwell Sike, or in healthe, in yll fame, or in good yours will I be, and with that onely thought comfort my self when that my hape is nowght.

Above is written, 'Pommi, oue'l sol occide i fiori, et l'herba'.

Tottel's version [11] differs so much that it should be quoted entire:

Set me wheras the sunne doth parche the grene,

Or where his beames do not dissolue the yse:

In temperate heate where he is felt and sene:

In presence prest of people madde or wise.

Set me in hye, or yet in lowe degree:

In longest night, or in the shortest daye:

In clearest skye, or where clowdes thickest be:

In lusty youth, or when my heeres are graye.

Set me in heauen, in earth, or els in hell, In hyll, or dale, or in the fomying flood:

Thrall, or at large, aliue where so I dwell:

Sicke, or in health: in euyll fame, or good.

Hers will I be, and onely with this thought

Content my selfe, although my chaunce be nought.

1] Dyvers thy death doo dyverslye bemone Some that in presence of that livelye hedd Lurked whose brestes envye with hate had sowne yeld Cesars teres vppon Pompeius hedd

5] Some that watched with the murdres knyfe with eyre thurst to drynke thy guyltles blood whose practyse brake by happye end of lyfe weape envyous teares to here thy fame so good But I that knewe what harbourd in that hedd

10] what vertues rare were temperd in that brest honour the place that such a iewell bredd 
THE MS. POEMS OF HENRY HOWARD, EARI, OF SURREY. 303

and kysse the ground where as thy coorse doth rest with vaporde eyes from whence suche streames avayle As Pyramus did on Thisbes brest bewayle H. S.

A note after the poem reads 'Here ende my Ld. of Surrey's Poems. No variants in $T$.

1] I salamon dauids sonne, king of Ierusalem

Chossen by god to teach the Iewes, and in his lawes to leade them confesse vnder the sonne, that euerey thing is uayne The world is false, man he is fraile, and all his pleasures payne

5] Alas what stable frute, may Adams childeren fynde In that they seke by sweate of browes, and trauill of their mynde we that liue on the earthe, drawe toward our decay Ower childeren fill our place a whille, and then they fade awaye suche chaunges maks the earthe, and dothe remoue for none

10] But sarues us for a place, too play, our tragedes vppon when that the restles sonne, westwarde his course hathe ronne

Towards the east he hasts as fast, to ryse where he begonne when hoorrey boreas, hathe blowen his frosen blaste Then Zephirus with his gentill breathe, dissolues the Ise as fast

15] fludds that drinke vpp smale broks, and swell by rage of rayne

Discharge in sees, which them repulse, and swallowe strayte againe these worldly pleasures (lord) so swifte they ronne their race That skace our eyes may them discerne, they bide so littell space what hathe bin, but is now, the like hereafter shall 20] what new deuice grounded so suer, that dreadeth not the fall 
what may be called new, but suche things in tymes past As time buryed and dothe reuiue, and tyme agayne shall waste

things past right worthey fame, haue now no brute at all Euen so shall dey suche things, as now, the simple wounders call

25] I that in dauides seate, sit crowned and reioyce That with my septer rewle the Iewes, and teache then with my uoyce

have serchied long to know, straunge things vnder the sonne

To see how in this mortall lyef, a suerty might be wonne

this kyndled will to knowe, straunge things for to desyer 30] God hathe grafte in our gredye breasts, a torment for our hier

the end of eache trauell, furthwith I sought to knoo I found them uaine mixed with gall, and burdend with muche woo

defaults of natures worke no mans hand may restore Whiche be in nomber like the sandes vppon the salte floods shore

35] then vaunting in my witte, I gan call to my mynd What rewles of wysdom I hadde taught, that elders could not find and as by contraries to treye, most things we use Mens follies and ther errors, eke I gan them all peruse $\mathrm{t}[\mathrm{h}]$ erby with more delight, to knowledge for to clime 40] But this I found an endles wourke of payne and losse of tyme

ffor he to wisdomes skoole, that doth applie his mynd the further that he wades ther in, the greater doubts shall find

[59a] And such as enterprice, to put newe things in ure of some that shall skorne their deuise, may well them selfes assure.

\section{finis.}

Notes on the text: 9 e of chaunges inserted above, hand uncertain. 13 the first o of hoorrey inserted above, hand uncertain; the e of blaste partially erased $-16 \mathrm{u}$ of repulse altered from some other letter. $-22 \mathrm{As}$ replaces (?) at, hand uncertain - 27 straunge replaced by all, hand un- 
certain. - 28 of to replaces some erased letter or letters. - 31 I replaces some erased word, hand uncertain - 35 gan replaces original gall, same hand. - 37 the copyist began the verse that elders, then crossed out these words. - 39 tyerby. - 41 skoole replaces skolle, same hand.

Found also in $A$. [32 a], with the following variants: 1 Davids, Kinge, Jerusalem. -2 Chosen, Jewes, lead. -3 under, every, vayne. -4 falce, frayle. - 5 frewt, children fynd. - 6 seeke, sweat, travaile. -7 lyve, earth, draw, decaye. -8 our, awhyle. -9 makes, earth, doth remove. 10 serves, to playe, trageddies uppon. - 11 restlesse, westward, cource hath. -12 Towardes, hastes, faste, wheare. - 13 hoarrye. - 14 gentle breath dissolves. - 15 floodds, drynck upp small brookes. - 16 Dischardge, Seas whiche, swallow straight agayne. - 17 Theise worldlye, Lord. 18 skarce, discearne, byde, lyttle. - 19 hath bene, lyke. - 20 devyce grownded, sure. -21 newe, thinges. -22 buried, doth revyre. - 23 Thinges, worthie, have, brewte. - 24 even shall dye suche thinges, symple wonders. -25 Davids, sitt Crowned, rejoyce. -26 rule, voyce. - 27 have searched, all thinges under. - 28 life, suretie. - 29 kendlid, know, thinges, desyre. - 30 hath, greedie brestes, tourment, hyre. - 31 travaile, forthwith, know. - 32 fownd, vayne myxed, moche woe. - 33 Defaultes, worke. - 34 nombre lyke, uppon, salt. - 35 witt, mynde. - 36 rules, wisdome, had, Elders, fynd. - 37 trye, thinges. - 38 their, errours. - 39 Therbye, clyme. 40 endlesse worke. - 41 for, wysdomes, mynde. - 42 furder, therein, greatter, fynd. - 43 suche, enterpryse, putt new thinges. - 44 devyce, selves.

The caesura is marked, and the following vs. begin with caps. : $1-3$, $5-9,12-17,23,29,32,35-38$.

\section{Cap. 2. Eccles.}

1] From pensif fanzies then, I gan my hart reuoke And gave me to suche sporting plaies, as laughter myght prouloke

but euen suche uain delights, when they moste blinded me Allwayes me thought with smiling grace, a king did yll agre then sought I how to please, my belly with muche wine 'To feede me fatte with costely feasts, of rare delights and fine and other plesures eke, too purchace me with rest In so great choise to finde the thing, that might content me best

but lord what care of mynde, what soddaine stormes of Ire 10] with broken slepes enduryd I, to compasse my desier

to buylde my howses faier, then sett I all my cure By princely actes thus straue I still, to make my fame indure

delicius gardens eke, I made to please my sight Anglia. N. $\mathbf{r}$. XVII. 
And grafte therin all kindes of fruts, that might my mouthe delight

15] condits by liuely springs, from their owld course I drewe For to refreshe the frutfull trees, that in my gardynes grewe of catell great encreace, I bred in littell space

Bondmen I bought I gaue them wifes, and sarued me with ther race

greate heapes of shining gold, by sparing gan I saue

20] with things of price so furnyshed, as fitts a prince to have to heare faier women sing, sometyme I did reioyce Rauyshed with ther pleasaunt times, and swetnes of their

lemans I had so faier, and of so liuely hewe

That who so gased in their face, myght well their bewtey voyce rewe

25] neuer erste sat theyr king, so riche in dauyds seate Yet still me thought for so smale gaine, the trauaile was to great

from my desirous eyes, I hyd no pleasannt sight Nor from my hart no kind of myrth, that might geue them delyght

which was the only freute, I rept of all my payne

[596] 30] To feade my eyes and to reioyce, my hart with all my gaine but when I made my compte with howe great care of mynd And herts vnrest that I had sought, so wastfull frutt to fynde then was I streken strayte, with that abused fier To glorey in that goodly witte, that compast my desyer

35] but freshe before myne eyes, grace did my fawlts renewe What gentill callings I hadd fledd, my ruyne to purswe what raging pleasurs past, perill and hard eskape What fancis in my hed had wrought, the licor of the grape the erroure then I sawe, that their fraile harts dothe moue

40] Which striue in vaine for to compare, with him that sitts aboue

in whose most perfect worcks, suche craft apperyth playne That to the least of them, their may no mortall hand attayne and like as ligh[t]some day, dothe shine aboue the night So darke to me did folly seme, and wysdomes beames as bright 
THE MS. POEMS OF HENRY HOWARD, EARL OF SURREY. 307

45] whose eyes did seme so clere, mots to discern and fynde But will had clossed follies eyes, which groped like the blynde

yet death and time consume, all witt and worldly fame And looke what ende that folly hath, and wisdome hath the same

then sayd I thus (oh lord) may not thy wisdome cure 50] The waylfull wrongs and hard conflicts, that folly doth endure

to sharpe my witt so fine, then why toke I this payne Now finde I well this noble serche, may eke be called vayne as slanders lothsome brute, soundes follies iust rewarde Is put to silence all be time, and brought in male r[e]garde 55] eun so dothe tyme deuoure, the noble blast of fame which showld resounde their glories great, that doo desarue the same

thus present changes chase, away the wonders past $\mathrm{Ne}$ is the wise mans fattal thred, yet lenger spunne to last then is this wredtched vale, our lief I lothed playne 60 ] When I beheld our frutles paynes, to compasse pleassurs

my trauayll this a vaile, hath me produced loo vayne

An heire unknowen shall reape the frute, that $I$ in sede

but whervnto the lord, his nature shall inclyne did sowe $[60 a]$ Who can fore knowe into whose handes, I must my goods resine

65] but lord how pleasannt swete, then seamd the idell liefe That neuer charged was with care, nor burdened with stryefe

and vile the gredye trade, of them that toile so sore 'To leaue to suche ther trauells frute that neuer swet therfore

what is that pleasant gaine, which is that swet relief 70] That showld delay the bitter tast, that we fele of our gref the gladsome dayes we passe, to serche a simple gaine The quiete nights with broken slepes, to fead a resteles brayne

what hope is left us then, what comfort dothe remayne Our quiet herts for to reioyce, with the frute of our payne 
75] yf that be trew who may him selfe so happy call As I whose free and sumptius spence, dothe shyne beyonde sewerly it is a gift, and fauor of the lorde them all

Liberally to spende our goods, the ground of all discorde and wretched hards haue they, that let their tressurs mold 80] And carrey the roodde that skorgeth them, that glorey in their gold

but I doo knowe by proofe, whose ryches beres suche brute

What stable welthe $\mathrm{m}[\mathrm{a}] \mathrm{y}$ stand in wast, or heping of finis. suche frute.

Notes on the text: 20 fitts or sitts, uncertain. - $51 \mathrm{r}$ of sharpe inserted above, hand uncertain.

Occurs also in $A$. [32 $b$ ], with the following variants: 1 pencife fancies, revoke. - 2 gave, playes, might provoke. - 3 even, vayne delightes, moste blynded. - 4 alwayes, smyling, agree. - 5 bellye, moche wyne. 6 fatt, costlye feastes, delightes, fyne. -7 pleasures, purchase. -8 choyce, fynd. - 9 Lord, I mynd, souddayne. - 10 sleapes endured, desyre. 11 buyld, fayre. - 12 strave, endure. - 13 Delicious. - 14 there in, kyndes, frutes, mowth. - 15 Condytes, lyvely springes, theire olde cource. - 16 frutefull treese, gardens. - 17 Cattell, lytle. - 18 gare, wyves, servde, their. - 19 Great heapps, shyning goolde, sparinge, save. 20 thinges, pryce, furnished, fytts, have. - 21 faire, singe somtyme, rejoyce. - 22 Ravyshed, their, pleasant tewnes, swetuesse. - 23 faire, lyvelye. - 24 gazed, might, bewtie. - 25 Never earst sate therr, ryche, Davids. 26 small gayne, travaile, so. - 27 desyrous, hydd, pleasaunt. - 28 kynde, myrthe, delight. - 29 whiche, onlye frute, reapt. - 30 feede mye, rejoyce, gayne. - 31 how, mynde. - 32 hartes, frute. - 33 stryken straight, fyer, - 34 glorye, witt, compaste, desyre. - 35 fresshe, mye, faultes. 36 gentyll, had fled, pursue. - 37 pleasures, escape. - 38 fancies, head, lycour. - 39 errour, hartes, move. - 40 whyche stryve, vayne, hym, syttes above. - 41 moste, workes, crafte appeareth. -42 leaste, there. -43 lyke, daye, doth sheene above. - 44 dark, follie seeme. - 45 seeme, cleare, motes, discearne. - 46 closed, whiche, lyke. - 47 tyme, worldlye. 48 end, follie. - 49 said, Lord. - 50 wronges, conflictes, follie. 51 sharppe, fyne, whye. -52 fynd, searche. -53 slaunders, sownds, just. - 54 scylence, betyme, small. - 55 even, doth, devoure. - 56 whiche, resownd, do deserve. - 57 chaunges chace. - 58 wyse, fatall threed, longer sponne. -59 wretchid, lyef. -60 frutelesse, pleasures. -61 travaile, availe, low. -62 seede, sow. -63 wheareunto, Lorde, enclyne. -64 know, goodes resyne. -65 Lord, pleasant, seamed, Idle lif. - 66 never chardged, burdenyd, strif. - 67 vyle, greedie, toyle. - 68 leave, their travailes, never sweatt therefore. -69 pleasaunt gayne, whiche, sweete. -70 shulde 
THE MS. POEMS OF IIENRY HOWARD, EARL OF SURREY. 309

delaye, taste, feele, greif. - 71 searche, symple gayne. - 72 quyett nightes the broken sleapes, feede, restlesse. - 73 lefte, doth. - 74 quyett hartes, rejoyce, frewte or with payne. - 75 If, self, happie. - 76 sumptuous, doth sheene beyond. - 77 Surelye, Guyft, favour, Lorde. - 78 Lyberallye, spend, grownd. - 79 wretchid hartes have, lett, treasures mowlde. - 80 carrye, redd, sckourdgeth, glorye, goolde. -81 do know, profe, rychesse bears. - 82 wealthe may, waste, heaping.

The caesura is marked throughout, and the following vs. begin with caps.: $1,3,15,17,19,21-23,25-27,39,47,49,50-53,58,61,71,74$, $75,77,78$.

\section{Capitulo 3. Eccles.}

1] Like to the stereles boote, that swerues with euery wynde the slipper topp of worldely welthe, by crewell prof I finde

Skace hathe the seade wherof, that nature foremethe man receuid lief when deathe him yeldes, to earth wher he began

5] The grafted plants with payn, wherof wee hoped frute to roote them vpp with blossomes sprode, then is our cheif porsute

That erst we rered vpp, we undermyne againe and shred the spraies whose grouthe, some tyme we laboured with paine

Eache frowarde thretning chere, of fortune maiks vs playne

10] and euery plesant showe reuiues our wofull herts againe Auncient walles to race, is our unstable guyse and of their wether beten stones, to buylde some new deuyse

[60b] New fanzes dayly spring, which vaade returning moo and now we practyse to optaine, that strayt we must forgoo

15] Some tyme we seke to spare, that afterward we wast and that we trauelid sore to knitt, for to unclose as fast In sober sylence now our quiet lipps we closse and with vnbrydled toungs, furth with our secret herts disclosse

Suche as in folded armes, we did embrace, we haate 20] whom strayte we reconsill againe, and banishe all debate My sede with labour sowne, suche frute produceth me to wast my lief in contraries, that neuer shall agree 
From god these heuy cares, ar sent for our vnrests and with suche burdens for our welth, he frauteth full our brests

25] All that the Lord hathe wrought, hath bewtey and good grace and to eache thing assined is, the proper tyme and place And graunted eke to man, of all the worldes estate and of eache thinge wrought in the same, to argue and debate

Which arte though it approche, the heuenly knowlege moste 30] to serche the naturall grounde of things, yet all is labor loste

But then the wandering eyes, that longe for suertey sought founde that by paine no certayne welth might in this world be bought

Who liueth in delight, and seke no gredy thryfte but frely spends his goods, may thinke it as a secret gifte

35] Fulfilled shall it be, what so the lorde intende which no deuice of mans witt, may advaunce nor yet defende

Who made all thing of nought, that Adams chyldren might lerne how to dread the Lord that wrought, suche wonders in their sight

The gresly wonders past, which tyme wearse owt of mynde 40] to be renewed in our dayes the Lord hath so assynde. Lo thuse his carfull skourge dothe stele on us vnware which when the fleshe hath clene forgott, he dothe a gaine repaire

When I in this uaine serche, had wanderyd sore my witt I saw a rioall throne wheras that iustice should haue sitt 45] In stede of whom I saw, wit/ fyerce and crwell mode wher wrong was set that blody beast, that drounke the giltles blode

Then thought I thus one day, the lord shall sitt in dorne to vewe his flock and chose the pure; the spotted haue no rome

Yet be suche skourges sent, that eache agreuid mynde 50] lyke the brute beasts that swell in rage, and fury by ther kynde His erroure may confesse, when he hath wreasteled longe 


\section{and then with pacience may him arme, the sure defence}

$$
\text { of wronge }
$$

[61a] For death that of the beaste, the carion doth deuoure unto the noble kynde of man, presents the fatall hower

55] The perfitt forme that god, hathe ether geuen to man or other beast dissolue it shall, to earth wher it began And who can tell yf that, the sowle of man ascende or with the body if it dye, and to the ground decende Wherfore eache gredy hart, that riches seks to gayne 60] gather may he that sauery frutte, that springeth of his payne

A meane conuenient welth, I meane to take in worth and with a hand of larges eke in measure poore it fourth For treasure spent in lyef, the bodye dothe sustayne the heire shall waste the whourded gold, a massed with muche payne

65] Ne may foresight of man, suche order geue in lyef for to know, who shall reioyce, their gotton good with Finis. stryef.

Notes on the text: 10 an creasure after showe; reniues replaces reioyce, different hand. - $16 \mathrm{c}$ of unclose crossed out. - $30 \mathrm{r}$ of serche inserted, hand uncertain. - 43 sore originally fore. - 44 wheras that replaced by eke wher, different hand. - 55 hathe ether geuen to man revised to hath geuen to ether man, different hand. - 61 final e seems to be erased from last word. - 62 a massed may be one word. - 66 fore inserted before know, hand uncertain.

Found also in $A .[33 b]$, with the following variants: 1 Lyke, stearlesse boate, swarves, everye. - 2 slypper toppe, worldly wealth, profe. 3 skarce hath, seede, whearof, formeth. - 4 receaved lyef, death hym, earthe wheare. - 5 plantes, payne whearof we, frewte. - 6 blossons spreadd, pursute. - 7 earst, reared upp, agayne. - 8 shredd, sprayes, growth somtyme, payme. - 10) every pleasaunt, revyves, hartes agayne. -- 11 walls. - 12 weather beaten, buyld, devyse. - 13 fancyes daylye springes whiche vade, mo. - 14 now inserted, obtayne, straight, forgo. 15 Somtyme, seeke, waste. - 16 travaild. - 17 scylence, quyett Iypps. 18 undbrydled tungues forthwith, secreat hartes disclose. - 19 hate. 20 whome straight, reconcycle again. - 21 seede, frewte. - 22 waste, never. - 23 God theise hearie, unrestes. - 24 wealth, fraughteth, brestes. -- 25 hath, bewtie. - 26 assigned. - 28 thing. - 29 whiche, thoughe, hearenlye knowledge. - 30 searche, grownde, thinges, labour. - 31 than, wandringe, suretye. - 32 fownd, payne, certen wealth. - 33 lyveth, seekes, greedie thrifte. - $3 \pm$ freely goodes, thinck, secreat gyfte. - 35 fulfilled, Lord intend. - 36 whiche, devyce, manns, defend. - 37 thinges, children. 
- 38 Learne. - 39 greeslye, weares out, mynd. - 40 renewyd. - 41 thus, carefull skourdge duth steale, unware. - 42 whiche, fleeshe, cleane, doth agayne repayre. -43 vayne searche, wanderid. -44 royall, where, justice shuld have sytt. - 45 steede, fearce, crewell moode. - 46 wheare wronge, sett, blooddye, dronck, bloode. - 47 sytt. - 48 vew, flocke, chuse, have. - 49 skourdges, aggreevid. - 50 beastes, furye, their. - 51 This errour, wrestlid. - 52 patience, hym. - 53 that beast, Carion, devoure. -54 kinde, presentes, houre. -55 perfect, thath geven, either. -56 dissolve, wheare. - 57 if, ascend. - 58 boddye, grownd descend. - 59 greedie, rychesse seekes. - 60 saverye frute, springethe. - 61 convenient wealth, worthe. -62 lardgesse, powre, forthe. -63 lyf, boddie doth. -64 horded goold a massed, moche. - 65 fore sight, geve, life. - 66 Ffor, whoe, rejoyce theire gotten, strife.

The caesura is marked, and the following vs. begin with caps.: 1,3 , $7,9,13,15,17,19,21,38,39,41,44,45,47,49-51,54,55,59,60,65,66$.

\section{Capitulo 4. Eccles.}

1] When I be thought me well vnder the restles soon by foolke of power what crewell wourks unchastyced were doon

I saw wher stoode a heard by power of suche opprest oute of whose eyes ran floods of teares that bayned all ther brest

5] Deuoyde of comfort clene, in terroure and distresse in whose defence none wolde aryse, suche rigor to represse Then thought I thus (oh Lord,) the dead whose fatall hower is clene roune owt more happy ar whom that the wormes deuoure

And happiest is the sede, that neuer did conceue

10] that neuer felt the waylfull wrongs, that mortall folke receue

And then I saw that welth, and euery honest gayne by trauill woune, and swete of browes gan grow into disdayne

Throughe slouthe of earles folke, whome eache so fatt dothe feade whose Idell hands doo nought but waast, the frute of other seeade

15] Which to them selves perswade that little gott with ease more thankefull is then kyndomes woon, by trauayle and disceace

A nother sort I saw, with out bothe frend or kynne 
THE MS. POEMS OF HENRY HOWARD, EARL Of SURREY. 313

whose gredy wayes yet neuer sought a faithfull frend to winne

[61b] Whose wretched corps no toile yet euer wery could

20] nor glutted euer wer their eyne, with heaps of shyning

But yf it might appeare to ther abused eyne

gould

to whose a vaile the trauill so, and for whose sake

they pyne

Then should they see what cause they haue for to repent the frutles paynes and eke the tyme that they in vayne haue spent

25] Then gan I thus resolue, more pleasant is the lyef of faythefull frends that spends their goods in commone

For as the tender frend appeasith euery gryef with out stryef

so yf he fall that lives alone, who shalbe his relyef The frendly feares ly warme, in armes embraced faste

30] who sleapes aloone at euery tourne dothe feale the winetr blast

What can he doo but yeld, that must resist aloone Yf ther be twaine one may defend the tother ouer throwne The single twyned cordes, may no suche stresse indure as cables brayded [thre fould] may, to gether wrethed swer

35] In better far estate stande children poore and wyse then aged kyngs wedded to will that worke with out

In prison haue I sene, or this a wofull wyght aduice

that neuer knewe what fredom ment, nor tasted of delyght

With such unhoped happ in most dispaier hath mete

40] with in the hands that erst ware giues to have a septure sett

And by coniures the seade of kyngs is thrust from staate wheron agreuyd people worke, ofteymes their hidden haat

Other with out respect, I saw a frend or foo with feat worne bare in tracing such, whear as the honours groo.

45] And at change of a prynce great rowtes reuiued strange which faine theare owlde yoke to discharg, reioyced in the change 
But when I thought to theise, as heauy euen or more shalbe the burden of his raigne, as his that went before And that a trayne like great upon the deade depend 50] I gan conclude eache gredy gayne, hath his vncertayne end

In humble spritte is sett, the temple of the Lorde wher yf thow enter loke thy mouth, and conscyence may accorde

Whose churtche is buylte of loue, and decte with hoote desyre

and simple fayth the yolden hoost, his marcy doth requyre 55] Wher perfectly for aye, he in his woord dothe rest with gentill eare to heare thy sute, and graunt to thy request

[62a] In boost of owtwarde works, he taketh no delight nor wast of wourds suche sacryfice unsaue[re]th in his Finis. sight

Notes on the text: 13 eache replaced by ease, probably same hand. - 15 gott altered from goot, same hand. - 34 thre fould inserted, different hand. -40 u of septure crossed out.. - 45 change replaced by deth, diff. hand. - 56 or grannt. -58 re of unsau[re]th inserted, prob. diff. hand.

Found also in $A$. [34b], with the following variants: 1 bethought, under, Sonne. -2 folke, powre, workes, unchastised, done. -3 wheare stood, Heard, powre. -4 their. -5 Devoyde, comforte cleane, terrours. -6 rygour. -7 o, howre. -8 cleane ronne (? roune) oute, happie are whome, devoure. - 9 Seede, never, conceave. -10 never, waillfull wronges, receave. - 11 than, sawe, wealth, everye. - 12 travile woune, sweatt, growe. - 13 through sloothe and carelesse, ease, doth feede. - 14 idle, do, but inserted, waste, seede. -15 whiche, lyttle. -16 thanckfull, than kingdomes wonne, travaile, disease. - 17 sorte, sawe, without both frind. - 18 greedye, yett never, frind, wymne. - 19 Corps, toyle, ever werye coulde. - 20 ever weare, eyen, heapes, goolde. - 21 if, their. - 22 availe they travaile, pynne. -23 shulde, have. -24 frutelesse, have. -25 gan, resolve, lyf. - 26 faithfull frends, goodes, common without strife. 27 frende appeaseth everye greif. - 28 if, lyves, whoe shall be, relief. 29 frendlye, lye, fast. - 30 whoe, alone, every, doth feele, wynter. 31 do, yelde, alone. - 32 there, twayne, overthrowne. - 33 syngle, Coards, endure. - 34 Cables, three folde may to gether wreathed sure. - 35 stand. - 36 kinges, without advyse. -37 pryson have, seene, wight. - 38 never knew, freedome, delight. - 39 suche, moste dispaire, mett. - 40 within, earst, gyves, have, Septer. - 41 Conjures, seede, kinges, state. - 42 wheare on a greeved, oft tymes, hydden hate. - 43 without, foe. - 44 withe feete, suche, goe. - 45 deathe, prince, revyred straunge. - 46 whiche 
fayne their olde, dischardge, rejoyced, chaunge. - 47 heavie even. 48 Shall be, bourden. - 49 lyke, uppon, dead. - 50 greedye, uncerten. 51 Sprite inserted, Temple. - 52 Wheare if, looke thie mowth, conscience. 53 Churche, buylt, love, deckt, hote. - 54 symple faith, golden ghoost, mercye. - 5̃ Wheare perfectlye, worde. - 56 gentle, thie, graunt, thie. - 57 booste, outward workes. - 58 waste, wordes, sacrifice, unsavereth.

- Finis.

The caesura is marked, and the following vs. begin with caps.: 1,5 , $7,9,11,17,19,23,25,27-29,31,32,35,37,41,43,45,48,51,53,55,57$.

\section{Capitulo 5. Eccles.}

1] When that repentant teares, hathe clensyd clere from ill the charged brest, and grace hathe wrought, ther in amending will

With bold demands then may, his mercy well assaile the speche man [s]ayth, with owt the which, request may not preuaile

5] More shall thy pennytent sighes, his endles mercy please then their Importune siuts which dreame, that words gods wrath appease

For hart contrit of fault, ia gladsome recompence and praier fruict of faythe wherby, god dothe with synne dispence

As ferfull broken slepes, spring from a restles hedde 10] by chattering of vnholly lippis, is frutles prayer bredde In wast of wynde I rede, vowe nought vnto the Lord wherto thy hart, to bynd thy will, freely doth not accord For humble uowes fullfilld, by grace right swetly smoks but bold behests, broken by lust, the wrath of god

15] Yet better with humble hert, thy frayltye to confesse then to bost of suche perfitnes, whose works suche fraud expresse

With fayned words and othes, contract with god no gyle sucle craft returns, to thy nown harme, and doth thy self defile

And thoughe the myst of sinne, perswad such error light 20] therby yet ar, thy owtward works, all dampned in his sight

As sondry broken dreames, vs dyuerslye abuse so ar his errors manifold, that many words dothe use 
With humble secret playnt fewe words of hotte effect honor thy Lord, alowance vaine, of uoyd desart neglect

25] Thoughe wronge at tymes the right, and welthe eke nede oppresse

thinke not the hand of Iustice slowe, to followe the redresse

For such unrightius folke, as rule with out dredd

by some abuse or secret lust, he suffereth to be led The cheif blisse that in earth, the liuing man is lent

30] is moderat welth, to nourishe lief, yf he can be content He that hath but one felde and gredely sekethe nought to fence the [tillers] hand from nede, is king within his thought

[62b] But suche as of ther golde, ther only Idoll make noe treasure may the rauen of there hungry hands asslake

35] For he that gapes for good, and hurdeth all his gayne trau[i]lls in uayne to hyde the sweet, that showld releue his payne

Wher is gret welth their showld, be many a nedy wight to spend the same and that should be, the riche mans cheif delight

The sweet and quiet slepes that weryd limmes oppresse

40] begile the night in diet thyne, and feasts of great excesse But wakerly the riche, whose lyuely heat with rest their charged boolks with change of meats cannot so sone dygest

An other [righteous] dome, I sawe of gredy gayne with busye cares suche treasures oft preseruyd to their bayne

45] The plenteus howsses sackt, the owners end with shame their sparkelid goods, their nedy heyres, that showld reioyce the same

From welthe dyspoyled bare, from whence they came they went clad in the clothes of pouerte as nature furst them sent Naked as from the wombe, we came yf we depart

50] with toyle to seeke that wee must leue, what bote to uexe the hart

What lyef leede testeye men that that consume their dayes 
In inwarde freets, untempred hates, at stryef with sum alwaies

Then gan I prayce all those, in suche aworld of stryffe as take the profitt of their goods, that may be had in lyffe 55] For sure the liberall hand, that hath no hart to spare this fading welthe, but powres it forthe, it is a uertu rare That maks welth slaue to nede, and gold becom his thrall clings not his gutts, with niggishe fare, to heape his chest with all

But feeds the lusts of kynde, with costely meats and wynne 60] and slacks the hunger and the thurst, of nedy folke that pynne

$\mathrm{Ne}$ gluttons feast I meane in wast of spence to stryue but temperat mealles the dulled spryts with ioye thus to reuiue

No care may perce where myrth, hath tempred such a brest the bitter gaull seasoned with swet suche wysdome Finis. may digest.

Notes on the text: 4 fayth, not altered to none, hand uncertain. 15 er of better crossed out. - 17 words alt. to works, hand uncertain. 27 out alt. to outer, prob. another hand; final e of drede erased; our: ms. note by Percy. - 29 the replaced by to, hand uncertain. - 32 toiling inserted before hand, then itself replaced by tillers, diff. hands. - 35 hordith: $m s$. note by Percy. - 36 e ins. after $\mathfrak{u}$ of trauells. - 40 second $\mathrm{n}$ ins. in thyne, hand uncertain. - 43 gredy replaced by righteous; gredy a clerical error through anticipation of the word later in the line; hand uncertain. - 48 armes: ms. note by Percy; furst alt. to fyrst. - 50 boote: ms. note by Percy. - 52 that that alt. to that those, and again to then that, diff. hands - $61 \mathrm{Ne}$ replaced by no, diff. hand.

Found also in $A$. [35 a], with the following variants: 1 repentaunt, hath cleansid cleare, yll. - 2 chardged, hath, there in. -3 bolde demamaundes [demands], mercye, assayle. - 4 speache, without, whiche, none prevayle. - a thye penitent, endlesse mercye. -6 importune sutes whiche, wordes god. -7 ffor, contryte. -8 prayer frute, faith whearby, doth, dispennce. - 9 fearfull, sleepes, restlesse hedd, -- 10 chattering, unbolly lypps, frutelesse, bredd. - 11 waste, wynd, reede, unto, Lorde. - 12 whereto thie, thie, freelye, accorde. - 13 vowes fufilld, sweetely smokes. -14 bolde behestes, lustes, God provokes. - 15 bet, hart, thye frayltie. - 16 boste, perfectnesse, workes, frawd. -17 workes, contracte, God, guyle. -18 such crafte retournes, thyne owne, thie, defyle. - 19 though, synne perswade, errour. - 20 therbye, are thie outward workes. - 21 sondrie, us dyverslye. - 22 are, errours manyfolde, wordes doth. - 23 secreat, few wordes, effecte. - 24 honour thie Lorde, alowaunce vayne, voyde desert neglecte. - 
25 wealth. -- 26 thincke, follow. - 27 Ffor, unrighteous, withouten. 28 our secreat, suffireth, ledd. - 29 chief, to lyving. - 30 moderate wealth, if. - 31 field, greedelye seeketh. - 32 tillers, neede. - 33 their goolde, their, Idolle. - 34 no, ravyn, their inserted, hungrye. - 35 Ffor, hordith. - 36 travailes, vayne, sweete, should releeve, paynne. - 37 Wheare, great wealth theare shulde, needy. - 38 shulde. - 39 sweete, quyet sleapes, wearied lymbs. - 40 beguyle, dyet thynne, feastes. - 41 wakerlye, lyvely. - 42 chardged boolkes, chaunge, meates can not, digeste. - 43 rightuous, saw, greedy. - 44 ofte preservid. - 45 plentuouse howses. - 46 sparkled goodes, needye heires, should rejoyce. - 47 Ffrom wealth dispoyled. 48 Cladd, armes of povertie, first. - 49 if, departe. - 50 we, leave, whate boote, vexe. - 51 lyfe lead testye, then that. - 52 inward freattes untempryed, strief, some alwayes. - 53 prayse, a world, strif. -54 proffit, lyfe. - 55 Lyberall. - 56 wealth, poores, forth, vertue. - 57 makes wealth inserted, slave, neede, goold become. - 58 Clinges, guttes. - 59 feedes, lustes, costlye, meates, wyne. - 60 slackes, honger, thirst, needye, pyne. - 61 No, feaste, waste, stryve. - 62 temperatte mealles, sprytes, joye, revyve. -63 pearce wheare mirth, suche. -64 . gall seasoned, sweete such wisdome. - Ffinis.

The caesura is marked, and the following vs. begin with caps.: 1, 7, $9,11,22,27,29,31,35,37,43,45,48,49,51-53,58,61,63$.

[63a] 1] Wher recheles youthe in a vnquiet brest set on by wrath revenge and crueltye after long warr pacyens had opprest and iustice wrought by pryncelye equitie

5] my deny then myne errour depe imprest began to worke dispaire of libertye had not david the perfyt warriour tought that of my fault thus pardon shold be sought

Found also in $A$. [28b], with the following variants: 1 Wheare rechelesse, unquyet. - 2 Sett, wrathe revendge, Creweltie. - 3 patience. -4 justice, equytie. -5 denny. -6 Lybertie. -7 perfect, taught. 8 shuld.

\section{Domine deus salutis. Psal. 98.}

1] Oh lorde vppon whose will dependeth my welfare to call vppon thy hollye name syns daye nor night I spare graunt that the iust request of this repentaunt mynd so perce thyne eares that in thy sight som fauour it may fynd

5] my sowle is fraughted full with greif of follies past my restles bodye doth consume and death approcheth fast 
THE MS. POEMS OF HENRY HOWARD, EARL OF SURREY. 319

lyke them whose fatall threde thy hand hath cut in twayne

Of whome ther is no further brewte which in their graues remayne

oh lorde thow hast cast me hedling to please my fooe 10] into a pitt all botomeles whear as I playne my wooe

the burden of thy wrath it doth me sore oppresse and sundrye stormes thow hast me sent of terrour and distresse

the faithfull frends ar fled and bannyshed from my sight and such as I have held full dere have sett my frendshipp

light

15] my duraunce doth perswade of fredom such dispaire that by the teares that bayne my brest myne eye sight doth appaire

yet did I neuer cease thyne ayde for to desyre with humble hart and stretched hands for to appease thy yre

wherfore dost thow forbeare in the defence of thyne 20] to shewe such tokens of thy power in sight of Adams lyne wherby eche feble hart with fayth might so be fedd that in the mouthe of thy elect thy mercyes might be spredd the fleshe that fedeth wormes can not thy loue declare nor suche sett forth thy faith as dwell in the land of dispaire

25] in blind endured herts light of thy lively name can not appeare as can not iudge the brightnes of the same nor blasted may thy name be by the mouth of those whome death hath shitt in sylence so as they may not disclose

the liuelye uoyce of them that in thy word delight 30] must be the trumppe that must resound the glorye of thy might

[63b] wherfore I shall not cease in chief of my distresse to call on the till that the sleape my weryd lymes oppresse and in the morning eke when that the slepe is fledd with floods of salt repentaunt teres to washe my restles bedd

35] within this carefull mynd bourdynd with care and greif why dost thow not appere oh lord that sholdest be his relief 
my wretched state beholde whome death shall strait assaile

of one from youth afflicted still that never did but waile

the dread loo of thyne yre hath trod me vnder feet

40] the scourgis of thyne angrye hand hath made deth seme

full sweet

like to the roring waues the sunken shipp surrounde great heaps of care did swallow me and I no succour found

for they whome no myschaunce could from my loue devyde ar forced for my greater greif from me their face to hyde.

Finis.

Note on the text: the marginal correction of the number of the Psalm sems to be in the same ink.

Found also in $A$. [28b], with the following variants: the Ps. is numbered 98, without correction. - 10 Lorde uppon, dependith. -2 uppon thie hollie, day. -3 just, mynde. -4 pearce, as in thie, some favour, fynde. -5 frawghted. -6 restlesse boddie, approchethe. -7 threede thye, cutt. -8 whom there, brute, whiche, graves. -9 Lorde, me cast headlong. - 10 bottomlesse wheare. - 11 bourden, thye wrathe. 12 sondrie. - 13 are fledd, banisht. - 14 suche, have, deare have. $15 \mathrm{Mye}$, dothe, freedome soche dispayre. -16 bane. -17 do, never ceace. -18 thyne. -19 whearfore doste. -20 shew, suche, thie powre, Adames. -21 Whearby eache feoble, faith. -22 mowthe, thye, thye. -23 flesshe, feedeth, thie love. - 24 setforth thie praise, dispare. -25 blynd, hartes, thie lyvely. -26 nor, judge. - 27 blazed, thie, mowthes. -28 shutt, scilence. - 29 lyvelye voyce, thie worde. - 30 resownd, glorie, thie. 31 Wherefore, ceace. - 32 wearied lymbs. - 33 sleape. -34 teares, restlesse. - 35 mynde burdenid. - 36 whye doste, appeare o Lorde, shuldest. -37 wretchid, deathe, streight. -38 wayle. -39 loe, trode, under feete. - 40 skourdges, angrie, deathe seeme, sweete. - 41 lyke, roving waves, suncken, surrownd. -42 heapps, fownd. -43 ffor, mischaunce, love. 44 to, greatter greif. - Ffins.

The caesura is marked, and the following vs. begin with caps.: 1,3 , $5,7,9-11,13,15,17,21,23,26,27,29-31,36,37$.

1] The so[u]dden stormes that heaue me to and froo had welneare pierced faith my guyding saile for I that on the noble voyage goo to succhor treuthe and falshed to assaile

5] constrayned am to beare my sayles ful 100 and neuer could attayne some pleasaunt gaile for vnto such the prosperous winds doo bloo as ronne from porte to porte to seke availe 
this bred dispayre whereof such doubts did groo

10] that I gan faint and all my courage faile but now my blage myne errour well I see such goodlye light King David giueth me.

Note on the text: 1 sonnden, prob. copyist's mistake.

Found also in $A$. [29b], with the following variants: 1 heave, frow. 2 pearced. - 3 Ffor. - 4 succour truthe, falshedd. - 5 full low. 6 never pleasant gayle. - 7 unto suche, prosperous wynds do blow. 8 avayle. - 9 bredd, whearof suche doubtes, grow. - 10 faynt, fayle. 11 Blage. - 12 Suche, gyveth.

[64a] Quum bonus Israel Deus. Ps. LXXIII.

1] Thoughe lorde to Israell thy graces plentuous be I meane to such with pure intent as fixe their trust in the Yet whiles the faith did faynt that shold haue ben my guyde

lyke them that walk in slipper pathes my feet began to slyde

5] whiles I did grudge at those that glorey in ther golde whose lothsom pryde reioyseth welth in quiet as they wolde to se by course of yeres what nature doth appere the pallayces of princely fourme succede from heire to heire from all such trauailes free as longe to Adams sede

10] neither withdrawne from wicked works by daunger nor by dread

wherof their skornfull pryde and gloried with their eyes as garments clothe the naked man thus ar they clad in vyce

thus as they wishe succeds the mischeif that they meane whose glutten cheks slouth feads so fatt as scant their eyes be sene

15] vnto whose crewell power most men for dred ar fayne to bend and bow with loftye looks whiles they vawnt in

thier rayne

and in their bloody hands whose creweltye that frame the wailfull works that skourges the poore with out regard

of blame

to tempt the living god they thinke it no offence

20] and pierce the symple with their tungs that can make no defence

suche proofes bifore the iust to cawse the harts to wauer be sett lyke cupps myngled with gall of bitter tast and sauer Anglia. N. F. XVII. 
then saye thy foes in skorne that tast no other foode but sucke the fleshe of thy elect and bath them in their bloode

25] shold we beleue the lorde [doth] know and suffer this ffold be he with fables vayne that so abused is

in terrour of the iust thus raignes inquititye armed with power, laden with gold and dred for crueltye then vayne the warr might seme that I by faythe mayntayne

30] against the fleshe whose false effects my pure hert wold distayne

for I am scourged still that no offence have doon by wrathes children and from my byrth my chastesing begoon

when I beheld their pryde and slacknes of thy hand I gan bewaile the wofull state wherin thy chosen stand

35] and as I sought wherof thy sufferaunce lord shold groo I found no witt cold pierce so farr thy hollye domes to knoo and that no mysteryes nor dought could be distrust till I com to the holly place she mansion of the iust where I shall se what end thy iustice shall prepare $40]$ for such as buyld on worldly welth and dye ther colours faire [64b] Oh how their ground is false and all their buylding vayne and they shall fall their power shall faile that did their pryde mayntayne

as charged harts with care that dreme some pleasaunt tourne

after their sleape fynd their abuse and to their plaint retourne

45] so shall their glorye faade thy sword of vengeaunce shall Vnto their dronken eyes in blood disclose their errours all and when their golden fleshe is from their backe yshorne the spotts that vnder neth wer hidd thy chosen shepe shall skorne

and till that happye daye my hert shall swell in [c]are 50] my eyes yeld teares my yeres consume bitwne hope and dispayre

loo how my spirits ar dull and all thy iudgments darke no mortall hedd may skale so highe but wunder at thy warke 


\section{alas how oft my foes have framed my decaye}

but when I stode in drede to drenche thy hands still did me stay

55] and in eache voyage that $I$ toke to conquer synne thow wert my guyd and gaue me grace to comfort me therin and when my withered skyn vnto my bones did cleue and fleshe did wast thy grace did then my simple sprits releue

in other succour then oh lord why should I trust

60] but onely thyn whom I have found in thy behight so iust and suche for drede or gayne as shall thy name refuse shall perishe with their golden godds that did their harts seduce

where I that in thy worde have set my trust and ioye the highe reward that longs therto shall quietlye enioye 65] and my vnworthye lypps inspired with thy grace shall thus forespeke thy secret works in sight of Adams race.

Finis.

Notes on the text: 8 the $\mathrm{i}$ of the first heire is inserted above, and the preceding e seems to have been crossed out, and then restored; hands uncertain. - 14 glutten alt. to glutted, diff. hand. - 18 final s of skourges crossed out. - 25 doth inserted after lord, diff. hand. -47 fleshe alt. to Heece, diff. hand. - 49 rare, alt. to care, diff. hand.

Found also in $A$. [29b], with the following; variants: 1 Lord. 2 suche, entent. - 3 whyles, shuld have bene. -4 walke, slypper, feete. - 5 whyles, glorye, their goold. - 6 lothesome, rejoyceth, quyet, wold. - 7 see, cource, yeares, appayre. - 8 pallaces, princelye forme Succeede. - 9 Ffrom, suche travailes, long, Adames sede. - 10 withdrawen, workes. - 11 whearof, sckornefull. - 12 are, cladd. - 13 wisshe succeads, myscheaf. - 14 glutted cheekes slowth feedes, skant, seene. - 15 Unto, powre, moste, dread are. - 16 lookes whyles, vaunt, raigne. - 17 blooddye handes, creweltie. - 18 walefull workes, sckourdge, without regarde. - 19 lyving, thinck. - 20 pearce, tongues. - 21 before, just, hartes, waver. -22 with cupps mingled, saver. - 23 say thie, sckorne, taste. - 24 suck, Hesshe, thie electe, bathe, blood. - 25 Shuld, beleve, Lorde doth, suffre. 26 Ffooled. - 27 juste, iniquitie. -28 powre, goold, dread, creweltie. 29 seeme, faithe. - 30 agaynst, flesshe, falce, effectes, hart. - 31 Ffor, scourdged, done. - 32 Children, birth, begounne. - 33 beholde, slacknesse, thye. - 34 bewayle, whearin thie. - 35 and whan, whearof, suffraunce Lord shuld grow. - 36 fownd, could pearce, thie, know. - 37 doubt. 38 come, hollie, mancion, just. - 39 wheare, see, thie justice. -40 suche, wealth corrected from some other spelling, prob. welth-, theire coulloures fayre. - 41 grownd, falce, buildinge. - 42 powres. - 43 Chardged hartes, 
dreames. - 44 ther, fynde, abvse, playnt. - 45 glorie fade thie. -46 unto, dronken. - 47 goolden fleece, back. - 48 spottes, undernethe weare hyd thie, sheepe, sckorne. - 49 happie. - 50 yelde, yeares, betwene. - 51 Loe, spirites are, thie judgementes dark. - 52 head, wonder, thie wark. 53 ofte, have, decay. - 54 whan, stoode, dreede. -55 tooke, conqueare. - 56 guyde, gave, therein. - 57 witherid, skynne unto, cleeve. 58 flesshe, waste thie, than, symple spirites releeve. - 59 others succours, 0 Lorde whye shuld. - 60 onlye thyne whome, have fownde, thie, just. - 61 dread, thye. -62 pearishe, goolden gods, hartes. -63 wheare, thie, have sett, joye. - 64 rewarde, longes, quyetlye enjoye. - 65 unworthie, thie, - 66 forespeake thie seacrett workes, Adames. - FFinis.

The caesura is marked, and the following vs. begin with caps.: $1-4$, $7,9,13,15-19,21,23,25,29,31,34-37,39,41,45,51,59,61$.

[65a] Exaudi Deus orationem meam. Ps. LV.

1] Giue eare to my suit lord fromward hide not thy face beholde herking in grief lamenting how I praye my fooes they bray so lowde and eke threpe on so fast buckeled to do me scathe so is their malice bent

5] care perceth my entrayles and traueyleth my spryte the greslye feare of death enuyroneth my brest a tremblynge cold clene ouerwhelmeth my hert 0 thinke I hadd I wings like to the symple doue this peryll myght I flye and seke some place of rest

10] In wylder woods where I might dwell far from these cares what spady way of wing my playnts shold thei lay on to skape the stormye blast that threatned is to me rayne those vnbrydled tungs breake that coniured league for I decyphred haue amydd our towne the stryfe

15] gyle and wrong kept the walles they ward both day and night

and whiles myscheif with care doth kepe the market stede whilst wickidnes with craft in heaps swarme through the strete

then my declared foo wrought me all this reproche by harme so loked for, yt wayeth halfe the lesse

20] for though myne ennemyes happ had byn not to preuaile I cold not have hidd my face from uenym of his eye It was a frendly foo by shadow of good will myne old fere and dere frende my guyde that trapped me where I was wont to fetche the cure of all my care 
25 ] and in his bosome hyde my secreat zeale to god such soden surprys quicke may them hell deuoure whilst I inuoke the lord whose power shall me defend my prayes shall not cease from that the sonne disscends till he his haulture wynn and hyde them in the see

30] with words of hott effect that moueth from hert contryte such humble sute o lord doth pierce thy pacyent eare It was the lord that brake the bloodly compackts of those that preloked on with yre to slaughter me and myne the euerlasting god whose kingdom hath no end

35] whome by no tale to dred he cold divert from synne the conscyence vnquyet he stryks with heuy hand and proues their force in fayth whome he sware to defend butter fales not so soft as doth hys pacyence longe $[65 b]$ and ouer passeth, fine oyle running not halfe so smothe 40] but when his suffraunce fynds that brydled wrath prouoks he threthneth wrath he whets more sharppe then any toole can fyle

friowr whose harme and tounge presents the wicked sort of those false wolves with cootes which doo their ravin hyde that sweare to me by heauen the fotestole of the lord

45] who though force had hurt my fame they did not touch my lyfe

such patching care I lothe as feeds the welth with lyes but in the thother $p[s]$ alme of David fynd I ease Iacta curam tuam super dominum et ipse to enutriet.

Finis.

Notes on the text: 7 of dred inserted after cold, diff. hand. $-11 \mathrm{e}$ inserted in spady; $\mathrm{i}$ of thei replaces orig. $\mathrm{n}$, same hand; later, word altered to they, diff. hand. - $15 \mathrm{kept}$ the walles alt. to do kepe walles, diff. hiond or hands. - 16 whiles myscheif alt. to whiles myscheif eke, and later to myscheif ioyned. - 18 then replaced by ne, diff. hand. -20 not replaced by for, diff. hand. - 21 not crossed out, diff. hand. -26 them hell alt. to hym hele, diff. hand. -47 phalme.

Found also in $A$. [30 $b$ ], with the following variants: 1 Geave, sute Lord, hyde, thie. -2 herken, greefe. -3 solowde. -5 pearceth, traveileth, spirit. - 6 greeslye, envyroneth. - 7 tremblinge colde of dread cleane overwhealmethe, hart. -8 thinck, had, winges lyke, dove. -9 perill might, seeke. - 10 woodes wheare, theise. - 11 speedie, wyng, playntes shuld they. - 13 Raine, unbrydled tongues, conjured. - 14 ffor, descyphred have, strif. - 15 guyle, the wanting, warde. - 16 and myschief joynede, steede. - 17 Whyleste wickednes, crafte, heapes. - $18 \mathrm{ne} \mathrm{my,} \mathrm{foe.} \mathrm{-}$ 
19 looked, half. - 20 thoughe, enemyes or ennemyes, bene for to. 21 coulde have hydd, venome. - 22 frendlye foe. - 23 olde feere, deare frend. - 24 wheare. - 25 bosom, God. - 26 suche soudden, quyck, hym self devoure. -27 Whylste, invoke, Lorde; powre. - 28 seace, discendes. - 29 aulture wynne (word alt.), Sea. - 30 wordes, whote effecte, moves, hart. - 31 suche, Lorde, pearce thie pacient. - 32 Lord, blooddie compactes. - 33 prelooked, Ire, slawghter. -- 34 everlasting, kingdome. - 35 dread, could dyvert. - 36 conscience unquyet, strykes, heavye. -37 proves, faith. - 38 falles, softe, his patience. - 39 over, fyne, roninng, half. - 40 fyndes, provokes. - 41 threatneth, whettes, anye. - 42 tongue presentes. 43 falce, coates whiche do, Ravyn. - 44 heaven, foote stoole, Lorde. 45 thoughe, touche, lif. - 46 Suche, feedes, wealth. - 47 other. 48 dominum. - The Latin line followed by id est, cast thie care uppon the Lord and he shall norishe the. - Ffinis.

The caesura is marked; and the following vs. begin with caps.: 1,5 , $7,8,10,13,22,27,32,46,48$.

1] Gyrtt in my giltlesse gowne / as I sytt heare and sowe I see that thinges are not in dead $\mid$ as to the owtward showe and who so lyst to looke | and note thinges somwhat neare Shall fynde wheare playnnesse seemes to haunte | nothing but craft appeare

5] for with indifferent eyes my self can well discearne how som to guyd a shyppe in stormes / styckes not to take the stearne whose skill and conninge tryed | in calme to steare a bardge they wolde sone shaw yow shold sone see it weare to great

a chardge

And some I see agayne | sytt still and say but small

10] that can do ten tymes more than they / that say they can do all whose goodlye gyftes are suche | the more they vnderstand the more they seeke to learne and know / and take lesse chardge in hand and to declare more playne / the tyme [f]lyttes, not so fast but I can beare right well in mynd / the song now sung and past

15] The awctour whearof cam | wrapt in a craftye cloke in will to force a flamyng fyre / wheare he could rayse no smoke 
If powre and will had mett / as it apppeareth playne the truth nor right had tane no place / their vertues had bene vayne

So that you may perceave / and I may saflye see

20] the innocent that giltlesse is | condempned sholde have be muche lyke untruth to this / the storye doth declare Wheare the elders layd to Susans chardge / meete matter to compare

They did her both accuse / and eke condempne her to and yet no reason right nor truthe / did lead them so to do

25] And she thus judged to dye / toward her death went forthe Ffraughted with faith a pacient pace / taking her wrong in worthe

but he that dothe defend / all those that in hym trust Did raise a Childe for her defence / to shyeld her from the unjust and Danyell chosen was | then of this wrong to weete 30] How, in what place and eke with whome / she did this cryme commytt he cawsed the Elders part / the one from the others sight and did examyne one by one / and chardged them bothe

Vndra Molberye trye / it was fyrst sayd the one say right The next namede a Pomegranate trye | whereby the truth was knowne

35] Than Susan was discharged / and they condempned to dye as right requeares and they deserve / that framcde so fowll a lye And he that her preserved | and lett them of their lust hath me defendyd hetherto | and will do still I trust. Ffinis.

Notes on the text: 13 slyttes. - 30 and before eke inserted, same hand. - 32 them inserted, same hand.

Variants in 'I' [198]: 6 seke for to take. -7 Whose practise yf were proued. - 8 Assuredly beleue it well it were to great. - 10 could. 14 full well. -16 With will. -17 had ioynde. - 21-38 missing.

[26a]

1] Laid in my quyett bedd, in study as I weare I saw within my troubled hed, a heape of thoughtes appeare and every thought did shew, so lyvelye in myne eyes 
that now I sight and then I smylde, as cawse of thought did ryse

5] I saw the lytle boye, in thought how ofte that he did wishe of Godd to scape the rodd / a tall yong man to be The yong man eke that feeles, his bones with paynes opprest

how he wold be a riche olde man | to lyve and lye att rest The ryche olde man that sees / his end draw on so sore

10] how he wolde be a boye agayne / to lyve so moche the more Wheare at full ofte I smylde / to see how all theise three from boy to man, from man to boy / wold chopp and chaunge degree

and musinge thus I thincke / the case is very straunge that man from wealth to lyve in woe / doth ever seeke to chaunge

15] thus thoughtfull as I laye / I saw my witheryd skynne how it doth shew my dynted Jawes | the flesshe was worne so thynne and eke my tothelesse chapps | the gates of my right way that opes and shuttes as I do speake | do thus unto me say Thie whyte and horishe heares / the messengers of age

20] that shew lyke lynes of true belief | that this lif doth asswage

bides the lay hand and feele | them hanging on thie chyn the whiche do wryte twoe ages past / the thurd now cumming in hang upp therfore the bitt / of thie yonge wanton tyme and thow that theare in beaten art | the happyest lif defyne

25] Wheare at I sight and said | farewell my wonted joye trusse upp thie pack and trudge from me / to every lytle boye

And tell them thus from me / theire tyme moste happie is Yf to their tyme they reason had | to know the truthe of this. Ffinis.

Variants in $T$. [30]: 4 doth. -16 dented chewes.

1] Eache beeste can chuse his feere / according to his minde and eke to shew a frindlie cheare | lyke to their beastly kynd a Lyon saw I theare / as whyte as any snow 
whiche seemyd well to leade the race / his porte the same did shew

5] uppon this gentyll beast $/$ to gaze it lyked me for still me thought it seemyd me / of noble blood to be and as he praunced before / still seeking for a make as whoe wolde say there is none heare / I trow will me forsake I might perceave a woolf / as whyte as whale his bone

10] a fayrer beast, a fressher hew / beheld I never none Save that her lookes wear fearce / and froward eke her grace toward the whiche this gentle beast | gan hym advaunce and with a beck full low / he bowed at her feete apace in humble wyse as who wold say | I am to farr unmeete

15] but suche a scornfull cheere | wheare with she hym rewarded

was never seene I trow the lyke | to suche as well deservid Wheare with she startt asyde / well neare a foote or twayne and unto hym thus gan she saye / with spight and great disdayne

Lyon she said yf thow / hadest knowen my mynde beforne

20] thow hadst not spentt thie travaile thus / and all thie payne forlorne

Do waye I lett the weete / thow shalt not play with me but raunge aboute; thow maiste seeke oute | some meeter feere for the forthwith he beatt his taile / his eyes begounne to flame I might perceave his noble hartt | moche moved by the same

25| Yet saw I him refrayne / and eke his rage asswage and unto her thus gan he say / whan he was past his rage Crewell you do me wronge / to sett me thus so light without desert for my good will | to shew me such dispight how can you thus entreat / a Lyon of the race

30] that with his pawes a crowned kinge / devoured in the place whose nature is to prea/uppon no symple foode as longe as he may suck the flesshe $\mid$ and drincke of noble bloode

[27b] Yf you be faire and fresshe | am I not of your hew and for my vaunte I dare well say | my blood is not untrew 
35] ffor yoy your self dothe know / it is not long agoe sins that for love one of the race / did end his life in woe In towre both strong and highe / for his assured truthe Wheare as in teares he spent / his breath | alas the more the ruthe

This gentle beast lykewise / who nothinge could remove

40] but willinglye to seeke his death | for losse of his true love Other ther be whose lyfe / to lynger still in payne against their will preservid is / that wold have dyed right fayne

but well I may perceave / that nought it movid you my good entent my gentle hart | nor yet my kynd so true

45] but that your will is suche / to lure me to the trade as other some full many yeares | to trace by crafte you made and thus beholde my kynd / how that we differ farr I seke my foes and you my frends | do threaten still with warr

I fawne wheare I an fedd | you flee that seekes to you

50] I can devoure no yelding pray | you kill wheare you subdue My kynd is to desyre / the honour of the field and you with blood to slake your thurst / of suche as to you yelde

Wherefore I wolde you wist | that for your Coy lookes I am no man that will be traynd / nor tanglyd bye suche hookes

55] and thoughe some list to bow / wheare blame full well they might and to suche beastes a currant fawne / that shuld have travaile bright

I will observe the law / that nature gave to me to conqueare suche as will resist $\mid$ and let the rest go free and as a Ffaulcon free / that soreth in the ayre

60 ] whiche never fedd on hand or lure / that for no stale doth care

While that I live and breathe / suche shall my custome be in wildnesse of the woodes to seeke/ my prea wheare pleasith me where many one shall rew / that never made offence thus your refuse agaynst my powre / shall bode them no defence 
THE MS. POEMS OF IIENRY HOWARD, EARL OF SURREY. 331

65 ] in the revendge wherof $\mid \mathrm{I}$ vowe and sweare therto a thowsand spoyles I shall commytt | I never thought to do and yf to light on you / my happ so good shall be I shall be glad to feede on that / that wold have fed on me and thus farewell unkynd / to whome I bent to low

70] 0 would you wist the shipp is safe / that bare his saile so low

[28a] Syns that a Lyons hart / is for a woolfe no pray with blooddye mowth of symple sheepe / go slake your wrath I say with more dispight and Ire / than I can now expresse whiche to my payne though I refrayne / the cause you may well gesse

75] As for becawse my self | was awthour of this game It bootes me not that by my wrath / I shuld disturbb Ffinis. the same.

Variants in T. [218]: 2 can shew. - 3 I late. -5 the gentle, it pleased. -6 he semed well. -10 of fresher. -11 were coy. -12 Vnto the which. -17 With that she. -20 nor al. -22 Go range. -23 With that he. -25 his wrath. - 35 your self haue heard. -37 both omitted. -40 to lese his life. - 41 whose liues. - 42 their willes preserued ar, right omitted. - 43 But now I doe, it moueth. - 47 our kyndes. 48 your frendes. -49 am fled. - 52 on such. -53 coyed. -54 be trapt, with such. - 55 lust to loue. - 56 of currant sort. - 60 nor lure nor. - 64 This your refuse. - 65 And for reuenge therof - 66 I thousand. - 69 bent and bow. -70 sailes. -72 With bloody mouth go slake your thirst on simple shepe I say.

1] This name o Lord howe greate | is fownd before our sight Yt fills the earthe and spreades the ayre / the great workes of thie might

for even unto thie powre / the heavens have geven a place and closyd it above their heades | a mightie lardge compace

5] thye prayse what clowde can hyde / but it will sheene agayne synce yonge and tender sucking babes / have powre to shew it playne whiche in dispight of those | that wold thie glorye hide hast put into such Infantes mowthes / for to confounde their pryde. 
Wherefore I shall beholde | thy fygurede heaven so hye

10] whiche shewes suche printes of dyvers formes / within the clowdye skye

As hills and shapes of men / eke beastes of sondrie kynde monstruous to our outward sight $\mid$ and fancyes of our mynde And eke the wanishe moone / whiche sheenes by night also and eache one of the wandring sterres | whiche after her doth goe

15] and how to kepe their course / and whiche are those that stands because they be thie wonderous workes | and labours of thie hands but yet among all theise / I aske what thing is man whose tourne to serve in his poore neede / this worke thow first began

Or whate is Adames sonne / that beares his fathers marke 20] for whose delyte and compforte eke / thow hast wrought all this warke

I see thow myndest hym moche | that doste rewarde hym so beinge but earthe to rule the earthe / wheare on hymself doth go

Ffrom Aungells substaunce eke | thow madeste hym differ small

Save one dothe chaunge his lif awhyle | the other not at all

25] The Sonne and Moone also | thow madeste to geve him light and eache one of the wandring sterrs | to twynckle sparkles bright

The ayre to geve hym breathe | the water for his health the earth to bring forth grayne and frute / for to encrease his wealth

and many mettalls to / for pleasure of the eye

[28b] 30] whiche in the hollow sowndyd grownd / in previe vaynes do lye The sheepe to geve his wool / to wrapp his boddie in and for suche other needefull thynges! the oxe to spare his skynne

The horsse even at his will | to beare hym to and fro and as hym list eache other beaste | to serve his turne also

35] The fysshes of the sea / lykewyse to feede hym ofte 
THE MS. POEMS OF HENRY HOWARD, EARL OF SURREY. 333

and eke the birdes whose feathers serve / to make his sydes lye softe

On whose head thow hast sett / A Crowne of Glorye to to whome also thow didest appoint / that honour shuld be do and thus thow madeste hym Lord | of all this worke of thyne 40] of man that goes, of beast that creapes / whose lookes doth downe declyne

of ffysshe that swymme below / of ffowles that flyes on hye of Sea that fyndes the ayre his rayne / and of the land so drye and underneath his feete / thow hast sett all this same to make hym know and playne confesse | that marveilous is thie name

45] and Lord whiche art our Lord / how merveilouse is it fownd the heavens doth shew, the earth doth tell $\mid$ and eke the world so rownd

Glorie therefore be geven / to thee first whiche art three and yet but one almightie God | in substaunce and degree as first it was when thow / the darcke confused heape 50] Clottid in one, didst part in fowre / whiche Elementes wee cleape and as the same is now / even heare within our tyme and ever shall here after be / when we be filth and slyme. Ffinis.

Notes on the text: 34 list inserted. - 45 the vei of merveilous corrected from some earlier spelling.

[31a]

1] Good Ladies you that have / your pleasure in exyle Stepp in your foote, come take a place / and mourne with me awhyle and suche as by their Lords | do sett but lyttle pryce Lett them sitt still it skills them not / what chaunce come on the dyce

5] but you whome love hath bound / by order of desyre to love your Lordes whose good desertes | none other wold requyre.

[31 6$]$ Come you yet once agayne / and sett your foote by myne whose wofull plight and sorowes great / no tongue may well defyne 
My Lord and love alas | in whome consystes my wealth

10] hath fortune sent to passe the Seas | in haserd of his health That I was wontt for to embrace / contentid myndes ys now amydd the foming floodds | at pleasure of the wyndes Theare God hym well preserve / and safelye me hym send without whiche hope my lyf alas | weare shortlye at an ende

15] [Whose absence yet, although my hope doth tell me plaine With short returne he comes anon, yet ceasith mot my payne.]

The fearefull dreames I have / oft tymes they greeve me so that then I wake and stand in dowbtt $\mid$ yf they be trew or no Somtyme the roring Seas | me seemes they grow so hye

20] that my sweete Lorde in daunger greate / alas doth often lye Another tyme the same / doth tell me he is comme and playng wheare I shall hym fynd | with T. his lytle sonne So forthe I goe apace / to see that lyfsome sight and with a kysse me thinckes / I say / now well come home my knight

25] Welcome my sweete alas / the staye of my welfare thye presence bringeth forthe a truce / betwixt me and my care

Then lyvelye doth he looke / and saluith me agayne and saith my deare how is it now / that you have all this payne

Wheare with the heavie cares | that heapt are in my brest 30] breakes forth and me dischardgeth cleane / of all my great unrest butt when I me awayke / and fyndes it but a dreame the angwyshe of my former woe / beginneth more extreame and me tourmentith so / that vnneth may I fynde some hydden wheare to steale the gryfe / of my unquyet mynd

35] Thus euerye waye you see / with absence bow I burne and for my wound no cure there is / but hope of some retourne

Save when I feele the sower | how sweete is felt the more it doth abate some of my paynes / that I abode before and then unto my self I saye | when that we two shall meete 40] but lyttle tyme shall seeme this payne / that joye shall be so sweete 
Ye wyndes I you convart / in chieffest of your rage that you my lord me safelye send | my Sorowes to asswage and that I may not long | abyde in suche excesse Do your good will to cure a wight | that lyveth in distresse. Ffinis. - Preston.

Notes on the text: 32 the $\mathrm{y}$ of angwyshe replaces $\mathrm{i}$.

Variants in $T$. [19]: 11 Whome I was wont tembrace with well contented minde. - 12 winde. - 13 Where, well him, sone him home me. 15-16 couplet in text. - 17 oft times do greue. - 18 That when I wake I lye in doute where. - 19 me semes do grow. -20 dere Lord ay me alas me thinkes I se him die. -22 with his faire little sonne. -24 I say welcome my lord. - 30 Breake, huge vnrest. - 31 finde. - 34 Sum hidden place, wherein to slake the gnawing of my mind. - 36 no cure I find, good return. - 37 Saue whan I think, by sowre. - 39 And then vnto my self I say when we shal meete. - 40 litle while, the ioy. - 41 I you coniure. -43 this excesse.

\section{Poems in Harl. Ms. 78.}

1] Of thie lyff Thomas the compas well marke । Not ay with full sayles the hyegh sees to beate ne be coward dreade forshunnynge stormes darke On shallowe shores the kell in perill freate |

5] Who gladly halsethe ye goulden meane Voyde of dayngers advisedly hathe his home not with lothesome moucke as a dene vnplayne nor palace lyke w[h]earat dysdayne may glome |

The lustyer pyne the greatter wyndes oft it reues

10] with violenter sueight turrettes stepe And lyghtninges assalt hiegh mountaynes \& cleves A hoort well scholed in ouer hartes depe

Hopethe ameniment in swet ferethe sower God yat sendethe withdrawethe Wynter smarte

15] Now yll not aye thus ones phebus to lower bowe vnbent shall cease \& vuice frame to sharpe

In streight estate appere thou hardie and stoute And so wysly when full vnlucky wynde All thie pufte sayles shall fyll loke well abuwte 20] Tayke in a rief hast is wast prof dothe fynde. Ffinis. 
Notes on the text: The poem was subjected to rather elaborate corrections, which are in the same hand, but in different ink, so that some considerable time may have elapsed between the copying of the poem and the correction of it. I have printed the unrevised version in so far as I can decipher it. -1 the alt. to this. - 3 forshunnynge alt. to forshonnynge. - 4 lest inserted before on; an earlier word is alt. to kell, but I cannot decipher it; in replaces withe, same ink. - 5 en inserted before halsethe, corrected from harsethe, same ink. -8 scribe started to write palicce, and alt. to palace. - 9 it crossed out. - 10 sueight alt. to sweightes, and fall inserted after it. - 11 assalt alt. to assalth. 13 hopeth alt. to hopes, prob. diff. hand; ameniment alt. to amendment. - 14 smarte preceded by sower crossed out, a clerical errour; smarte alt. to sharpe. - 15 phoebus to was orig. phebus, tollowed by some word that has been scratched out. - 16 cease preceded by seace crossed out; vuice alt. to voyce. -19 abuwte alt. to abowte.

Variants in T. [27]: 3 in shonning. -4 thy keel. -5 Who so. 7 vncleane. -9 The lofty pyne the great winde often riues. -10 swey falne. - 11 And omitted. - 12 well stayd in ouerthwartes depe. 13 amendes, doth feare the -14 sharp. -16 With bow, and frame to harp.

[30b] 1] I that vlisses yeres have spent to seeke Penelope

fynde well the foyle I have ment to say yat was not soo

5] Sins Troilus cause hathe caused me from Crised for to goo

And to repent Ulisses truthe in seas and storme skyes of raginge will \& wanton youthe

10] wherewith I have tossed sore from Cillas seas to Carribes clives vppone the drowninge shore

wheare I sought heaven ther founde I happe ffrom daynger vnto deahte

15] lyke vnto the mouse that treades the trappe in hope to fynde her fode and bytes the breade yat stoppes his brethe for in lyke case I stode

Tyll now repentance hastethe hym

20] to further me so fast

That wheare I sanke now ther I swyme And have bothe streame and wynde 
THE MS. POEMS OF HENRY HOWARD, EARL OF SURREY. 337

And lucke is good yf yt my last

that any mane may fynde.

Ffinis.

Variants in $T$. [241], where the poem is not assigned to Surrey: 2 finde. - 3 what folly. - 7 to bewaile. - 9 wanton will and raging youth. - 10 Which we have. - 11 Sicilla to Caribdis. - 21 there now. 24 - : That where I perished, safe I passe,

And find no perill there:

But stedy stone, no ground of glasse,

Now am I sure to saue,

And not to flete from feare to feare,

Such anker hold I haue.

[55a]

Poem in Add. Ms. 17492.

1] o happy dames that may enbrayes

the ffrwte off your delyet

helpe to be walle the woffulle casse

$\&$ eke the hewy plyet

5] off me that wontede to rejoyes

the ffortwne offe my pleassante chyes

good lades helpe to ffelle my mowernenge woyce.

en a shepe ffrawoghte with remiemberances

off wordes \& pleassures paste

10] he ssaylles that haytht en guvernances

my lyffe whylle et maye laste

with scaldenge sseythes ffor wante off gayle

ffurtheringe his hope that is his ssaylle

to warde me the sswete porte off hes awalle

15] alas howe ofte in dremes I see

thoos yees that were my ffoode

wyche ssumetyme sso dellyted me

that yet they do me good

where with I wake with his retourne

20] whoosse abssente fflamme dootht make me boren

but whan I ffynde the lake lorde howe I mowren.

[55b] whan owther lowers en armes acrosse

rejoyes ther cheffe dellyet

drowened en teares to mowren my losse

25] I stande the better nyghtes

Anglin. x. r. Xill. 
in my wyndowe wher I maye ssee beffore the wyndes howe the clowdes ffleye loo whate amarryner lowe hays made me $\&$ en grene wawes when the ssallte ffloode 30] dootht sswalle by rayges off wynde a thwssande ffaynsys en that moode assalles my resteles mynde allas now drenches my sswete ffoo that with sspoyle off my harte ded goo

35] \& lyfte me but allas whye ded he sso $\&$ when the ssces wax clame agane to chasse ffrom me anoye my dowteffwlle hopee makes me to playne sso drede cwtes off my joye

40] thus es my mowrtht meyngled with woo $\&$ off eyche thowet a dowete dowtht growe nowe he comes wylle he cume allas no no.

Notes on the text: The hand is very slovenly; words and even lines are scratched out to be replaced by slightly different spellings. - 1 enbrays. - 12 partly rewritten, without change. - $15 \mathrm{I}$ in replaced by in. 16 orig. ffodde. - 19 his rewritten, orig. retorene. - 24 orig. drowenede en teyeres to (?) moweren. - 28 me rewritten. - 29 (?) way started, then scratched out. - 31 orig. ffayncys. - 32 orig. hartte. - 38 orig. payne. - 42 he cume inserted above.

The first stanza occurs also in Harl. [30 b], with the following variants: 1 Oh happie, yat, imbrace. - 2 fructe, or friute, or fruite; your delight. 3 Helpe, bewayle, wofull case. - 4 heavie plyght. - 5 Of, yat wonted, reioyse. - 6 fortune; pleasaunt choyse. - 7 Good, fyll, morninge voyce.

Variants in T. [15]: 8 In ship, freight with rememberance. 9 thoughts. - 10 gouernance. - 11 wil last. - 12 lack. - 20 did. 30 rise, rage. -34 the spoyle. - 40 my wealth.

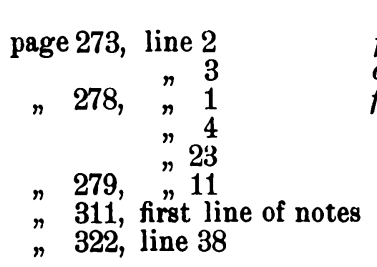

\section{Corrections.}

\begin{tabular}{|c|c|c|c|}
\hline \multicolumn{4}{|c|}{$\begin{array}{l}\text { for of Surrey read } \\
\text { after }[T .] \text { insert [Tottel] }\end{array}$} \\
\hline for & of the & read & \\
\hline$n$ & authography & $"$ & orthography \\
\hline & two books & $"$ & one book \\
\hline & Jilst & $"$ & jusciuts \\
\hline & & $"$ & the \\
\hline
\end{tabular}

Frederick Morgan Padelford.

\section{UNivergity OF Washington, Seattrle, Washington.}

